\title{
Link between Aluminum and the Pathogenesis of Alzheimer's Disease: The Integration of the Aluminum and Amyloid Cascade Hypotheses
}

\author{
Masahiro Kawahara ${ }^{1}$ and Midori Kato-Negishi ${ }^{2}$ \\ ${ }^{1}$ Department of Analytical Chemistry, School of Pharmaceutical Sciences, Kyushu University of Health and Welfare, \\ 1714-1 Yoshino-cho, Nobeoka-shi, Miyazaki 882-8508, Japan \\ ${ }^{2}$ Institute of Industrial Science (IIS), The University of Tokyo, 4-6-1 Komaba, Meguro-ku, Tokyo 153-8904, Japan
}

Correspondence should be addressed to Masahiro Kawahara, kawamasa@phoenix.ac.jp

Received 15 September 2010; Revised 29 November 2010; Accepted 5 January 2011

Academic Editor: Paolo Zatta

Copyright ( $) 2011$ M. Kawahara and M. Kato-Negishi. This is an open access article distributed under the Creative Commons Attribution License, which permits unrestricted use, distribution, and reproduction in any medium, provided the original work is properly cited.

\begin{abstract}
Whilst being environmentally abundant, aluminum is not essential for life. On the contrary, aluminum is a widely recognized neurotoxin that inhibits more than 200 biologically important functions and causes various adverse effects in plants, animals, and humans. The relationship between aluminum exposure and neurodegenerative diseases, including dialysis encephalopathy, amyotrophic lateral sclerosis and Parkinsonism dementia in the Kii Peninsula and Guam, and Alzheimer's disease (AD) has been suggested. In particular, the link between aluminum and Alzheimer's disease has been the subject of scientific debate for several decades. However, the complex characteristics of aluminum bioavailability make it difficult to evaluate its toxicity and therefore, the relationship remains to be established. Mounting evidence has suggested that significance of oligomerization of $\beta$-amyloid protein and neurotoxicity in the molecular mechanism of AD pathogenesis. Aluminum may play crucial roles as a cross-linker in $\beta$-amyloid oligomerization. Here, we review the detailed characteristics of aluminum neurotoxicity based on our own studies and the recent literatures. Our aim is to revisit the link between aluminum and $\mathrm{AD}$ and to integrate aluminum and amyloid cascade hypotheses in the context of $\beta$-amyloid oligomerization and the interactions with other metals.
\end{abstract}

\section{Introduction}

Aluminum ( $\mathrm{Al})$ is abundantly distributed in our environment, and compounds containing $\mathrm{Al}$ have been used in manufacturing (e.g., clays, glasses, and alum) for centuries. Despite its abundance, $\mathrm{Al}$ was first isolated as an element in 1827 , and its use as being a silvery metal began only after 1886. $\mathrm{Al}$ is a new metal in this context. Because of its beneficial characteristics such as a lightweight, nonmagnetic, malleable, and ductile element, Al has a widespread and important use in industrial applications and consumer products. $\mathrm{Al}$ is also used in cooking utensils and in pharmacological agents including antacids and antiperspirants from which the element enters the human body.

$\mathrm{Al}$ is not essential for life. On the contrary, $\mathrm{Al}$ is a well established neurotoxin and is suspected to be linked with various neurodegenerative diseases including Alzheimer's disease (AD), amyotrophic lateral sclerosis (ALS), and Parkinsonism dementia in the Kii Peninsula and Guam [1], and the Gulf War syndrome [2].

In particular, a possible relationship between $\mathrm{Al}$ and the pathogenesis of $\mathrm{AD}$ has been discussed for several decades [3-7]. AD is a severe senile type of dementia first reported in 1906. The pathological hallmarks of $\mathrm{AD}$ are the deposition of extracellular senile plaques, intracellular neurofibrillary tangles (NFTs), and the selective loss of synapses and neurons in the hippocampal and cerebral cortical regions. The major component of NFTs is the phosphorylated tau protein. Senile plaques are largely comprised of $\beta$-amyloid protein $(\mathrm{A} \beta \mathrm{P})$ [8]. The hypothesis that $\mathrm{Al}$ is an environmental contributor to the pathogenesis of $\mathrm{AD}$, termed the "aluminum hypothesis", was proposed in the 1960s based on 
various neurotoxicological, analytical, and epidemiological findings [9-11]. In spite of these findings, the aluminum hypothesis has been the subject of much debate and criticism for several decades. During this period, great progress was made in AD research. Particularly, numerous studies have supported the idea termed "amyloid cascade hypothesis", namely that the conformational changes of $\mathrm{A} \beta \mathrm{P}$ and its neurotoxicity play a central role in $\mathrm{AD}$ pathogenesis [12, 13]. $\mathrm{Al}^{3+}$ and other metals including $\mathrm{Zn}^{2+}, \mathrm{Cu}^{2+}$, and $\mathrm{Fe}^{3+}$ influence the oligomerization and conformational changes of $\mathrm{A} \beta \mathrm{P}$ as cross-linkers, and, therefore, their implications are important in this context. Furthermore, increasing evidence suggests the implication of these metals in the pathogenesis of $\mathrm{AD}$ [14-16]. Al binds to various metal-binding proteins and influences homeostasis of other metals.

We review here the detailed characteristics of aluminum neurotoxicity based on our own studies and the recent literature. Our aim is to update the various adverse effects of $\mathrm{Al}$ and revisit the link between $\mathrm{Al}$ and $\mathrm{AD}$ based on new findings on Al-induced conformational changes and metalmetal interactions.

\section{Neurotoxicity of Aluminum Update}

2.1. Effects of Al on the Memory Disorder of Human: Historical Overview. An association between $\mathrm{Al}$ poisoning and memory disorder in humans was first reported in 1921 [17]. Later, it was shown that the intracerebral administration of $\mathrm{Al}$ induced epilepsy in experimental animals [18]. As a component of dialysis solutions or Al-containing pharmacological compounds, $\mathrm{Al}$ is known to cause various dialysis-related disorders, including osteomalacia (aluminum bone disease), microcytic anemia, $\beta_{2}$-microglobulin-associated amyloidosis [19], and dialysis encephalopathy in hemodialysis patients [20].

The accidental contamination of $\mathrm{Al}$ into drinking water occurred and more than 20,000 persons were exposed to high level of $\mathrm{Al}$ at 1988 in Camelford (Cornwall, UK). Residents exposed to contaminated Al exhibited various symptoms related to cerebral impairments such as loss of concentration and short term memory in a 10-year follow-up study [21].

Martyn et al. reported a high incidence of $\mathrm{AD}$ in areas with a high level of $\mathrm{Al}$ in the drinking water in England and Wales [11]. A considerable number of studies have provided evidence to support an association between $\mathrm{AD}$ and $\mathrm{Al}$ in drinking water after this initial report [22]. Frecker reported on a Norwegian area where high $\mathrm{Al}$ concentrations in drinking water were linked with high dementia mortality [23]. Neri and Hewitt found a positive relationship between $\mathrm{Al}$ in drinking water and AD risk in Canada [24]. Forbes and McLachlan demonstrated a greater risk of $\mathrm{AD}$ in Canadian areas where concentrations of $\mathrm{Al}$ are high and those of fluoride are low [25]. Rondeau et al. demonstrated that high daily intake of $\mathrm{Al}$ was correlated with increased risk of dementia or cognitive decline in a 15-year follow-up French cohort study [26-28]. These studies suggest that Al has adverse effects on human memories and causes dementia when it enters the brain.
2.2. Effects of Al on the Central Nervous System In Vitro or In Vivo. Despite it's environmental abundance, $\mathrm{Al}$ is not an essential element for living organisms, and no enzymatic reaction requires $\mathrm{Al}$. $\mathrm{Al}$ is reported to influence more than 200 biologically important reactions and to cause various adverse effects on the mammalian central nervous system (CNS) (Table 1). These include crucial reactions for brain development such as the axonal transport, neurotransmitter synthesis, synaptic transmission, phosphorylation or dephosphorylation of proteins, protein degradation, gene expression, and inflammatory responses.

$\mathrm{Al}$ exhibits only one oxidation state, $\mathrm{Al}^{3+} \cdot \mathrm{Al}^{3+}$ has affinity for negatively charged, oxygen-donor ligands. Inorganic and organic phosphates, carboxylate, and deprotonated hydroxyl groups form strong bonds with $\mathrm{Al}^{3+}$. Owing to these chemical characteristics, $\mathrm{Al}^{3+}$ binds to the phosphate groups of DNA and RNA, affecting DNA topology and influencing the expression of various genes essential for brain functions. Lukiw et al. reported that nanomolar levels of $\mathrm{Al}^{3+}$ were sufficient to influence neuronal gene expression $[33,35]$.

$\mathrm{Al}^{3+}$ also binds to the phosphate groups of nucleoside di- and triphosphates, such as ATP and can thus influence energy metabolism. Furthermore, Al inhibits the functions of various protein kinases and phosphatases.

$\mathrm{Al}^{3+}$ has very low ligand-exchange rate in comparison to other metals. For example, the ligand-exchange rate of $\mathrm{Mg}^{2+}$ is $10^{5}$ times faster than that of $\mathrm{Al}^{3+}$, and therefore, $\mathrm{Al}^{3+}$ inhibits enzymes with $\mathrm{Mg}^{2+}$ cofactors. $\mathrm{Al}^{3+}$ also inhibits biological processes involving rapid $\mathrm{Ca}^{2+}$ exchange: the exchange rate for $\mathrm{Al}^{3+}$ is $10^{8}$ times slower than that of $\mathrm{Ca}^{2+}$. These properties make $\mathrm{Al}$ useless in enzymatic reactions and increase its half-life in the human body. We show the typical effects of $\mathrm{Al}$ in Figure 1.

$\mathrm{Al}^{3+}$ has strong positive charges and a relatively small ionic radius in comparison to other metal ions such as $\mathrm{Ca}^{2+}, \mathrm{Zn}^{2+}$, and $\mathrm{Na}^{+}$(Figure 2). Thus, $\mathrm{Al}^{3+}$ firmly binds to metal-binding amino acids (histidine (His), tyrosine (Tyr), arginine (Arg) etc.) or phosphorylated amino acids and acts as a cross-linker; this property has made it useful as a leather tanning agent. By binding to various proteins, $\mathrm{Al}$ can cause the oligomerization of proteins, inducing conformational changes that can inhibit their degradation by proteases. Strong binding of $\mathrm{Al}^{3+}$ to phosphorylated amino acids promotes the self-aggregation and accumulation of highly phosphorylated cytoskeleton proteins, including neurofilament and microtubule-associated proteins (MAPs), and so forth [58].

Consequently, Al causes apoptotic death of neurons and glial cells. Chronic administration of Al impairs longterm potentiation (LTP), which is a form of synaptic information storage well-known as a paradigm of memory mechanisms. Al also impairs various enzymes including those related to neurotransmitter synthesis and thus affects the neurotransmitter content. $\mathrm{Al}^{3+}$ also inhibits voltagegated $\mathrm{Ca}^{2+}$ channels and neurotransmitter receptors, and impairs synaptic transmission. Finally, Al causes spatial memory deficit, influences emotional reactivity, and impairs various brain functions related to learning and memory. 
TABLE 1: Effects of aluminum on the central nervous system.

References

(1) Nucleus and gene expression

Binding to DNA

Binds to histone-DNA complex and induces conformational changes of chromatin.

Induces topological changes of DNA.

Altered gene expression

Induces decreased expression of neurofilament and tubulin.

Induces altered expression of genes of neurofilament, APP, and neuron specific enolase.

Induces decreased expression of transferrin receptor.

Induces altered expression of RNA polymerase I.

Induces downregulation of mitochondrial cytochrome $\mathrm{c}$ oxidase.

Induces altered expression of calbindin-D28k.

Induces decrease in the expression of nerve growth factor (NGF) and brain derived neurotrophic factor (BDNF).

Induces expression of pro-inflammatory genes and pro-apoptotic genes.

Induces elevated expression of APP.

Induces altered expression of oxidative stress marker genes (SOD1, glutathione reductase, etc.).

Induces decreased expression of neprilysin.

Induces altered expression of $\beta$-APP secretase (BACE1 and BACE2).

\section{(2) Cellular functions}

Energy metabolism

Inhibits the activity of hexokinase

Inhibits the activity of glucose-6-phosphate dehydrogenase

$[48,49]$

Causes mitochondrial dysfunction and depletion of ATP alpha-ketoglutarate dehydrogenase $(\mathrm{KGDH})$, isocitrate dehydrogenase-NAD ${ }^{+}(\mathrm{IDH})$, fumarase (FUM), aconitase $(\mathrm{ACN})$, and cytochrome c oxidase (Cyt C Ox)).

Phosphorylation and dephosphorylation

Inhibits the activity of protein phosphatase.

Increases the activity of protein kinase $\mathrm{C}$ and cytoskeleton proteins.

Accelerates phosphorylation and accumulation of neurofilament.

Enhances $\mathrm{Ca}^{2+} /$ Calmodulin dependent protein kinase activity.

Accelerates phosphorylation of MAP 2 and neurofilament.

Inhibits dephosphorylation of tau.

Induces nonenzymatic phosphorylation of tau.

Abnormal accumulation of proteins

Causes the conformational change and the accumulation of neurofilament and MAP1A, MAP1B.

Accelerates the phosphorylation of tau and its accumulation.

Causes the accumulation of tau protein in neuroblastoma cells or in primary cultured neurons.

Causes the accumulation of tau protein in experimental animals.

$[33,62,63]$

Causes neurofibrillary degeneration in vivo.

Causes the accumulation of $\mathrm{A} \beta \mathrm{P}$ in cultured neurons or in neuroblastoma cells.

Causes the accumulation of $\mathrm{A} \beta \mathrm{P}$ in vivo.

Neurotransmitter release

Inhibits glutamate release.

Impairs synaptic transmission.

Inactivates glutamate dehydrogenase.

Inhibits NMDA-type glutamate receptor.

Inhibits choline acetyl transferase and tyrosine hydroxylase, glutamate decarboxylase. 
Table 1: Continued.

\begin{tabular}{|c|c|}
\hline & References \\
\hline Influences acetyl-CoA and inhibits acetylcholine release. & {$[75]$} \\
\hline Activates monoamine oxidase. & {$[76,77]$} \\
\hline Inhibits dopamine beta-hydroxylase. & [78] \\
\hline Inhibits uptake of serotonin and noradrenalin in synaptosomes. & [79] \\
\hline \multicolumn{2}{|l|}{ Channel inhibition } \\
\hline Influences the activities of $\mathrm{Na}^{+}$channels and $\mathrm{K}^{+}$channels. & {$[80]$} \\
\hline Enhances the voltage-activated $\mathrm{Na}^{+}$channels. & {$[81]$} \\
\hline Inhibits the voltage-gated calcium channel. & {$[70,82]$} \\
\hline Inhibits the $\mathrm{IP}^{3}$-mediated $\mathrm{Ca}^{2+}$ release. & [83] \\
\hline \multicolumn{2}{|l|}{ Others } \\
\hline Influences GTP binding proteins as aluminum fluoride. & {$[84]$} \\
\hline Inhibits GAP junction. & [85] \\
\hline Inhibits axonal transports. & {$[86]$} \\
\hline Binds to calmodulin and inhibition of calmodulin-binding enzymes. & {$[87]$} \\
\hline Induces inflammatory responses. & {$[88]$} \\
\hline \multicolumn{2}{|l|}{ (3) Membrane lipids } \\
\hline \multicolumn{2}{|l|}{ Peroxidation } \\
\hline Accelerates iron-induced membrane lipid peroxidation. & [89] \\
\hline Enhances lipid peroxidation in liposomes. & [90] \\
\hline Induces peroxidation of myelin lipids in vivo. & [91] \\
\hline Increases peroxidation products (malondialdehyde). & {$[59]$} \\
\hline \multicolumn{2}{|l|}{ Membrane properties } \\
\hline Causes the change the lipid/phospholipids profiles of myelin in vivo. & [92] \\
\hline Induces the change in membrane physical properties (surface potential, lipid fluidity, and lipid arrangement). & [91] \\
\hline Induces the change of membrane fluidity. & [93] \\
\hline \multicolumn{2}{|l|}{ (4) Higher functions } \\
\hline \multicolumn{2}{|l|}{ Cell death } \\
\hline Causes the apoptotic neuronal death. & {$[94,95]$} \\
\hline Causes the apoptosis of astrocytes. & [96] \\
\hline Causes the death of motor neuron. & {$[97,98]$} \\
\hline \multicolumn{2}{|l|}{ Behavior, learning, and memory, others } \\
\hline Inhibits long term potentiation (LTP). & {$[99,100]$} \\
\hline Causes learning disorder or memory deficit in experimental animals. & {$[101-103]$} \\
\hline Influences electrical activity in hippocampus and inhibits spatial learning memory deficit in aging rats. & {$[104]$} \\
\hline Causes memory deficit in AD model mice. & {$[105,106]$} \\
\hline Causes encephalopathy in dialysis patients. & {$[20]$} \\
\hline Causes encephalopathy in patients with renal failure. & {$[107]$} \\
\hline
\end{tabular}

These adverse effects may be involved in the mechanisms that underlie Al-induced memory disorder.

\section{Link between Al and AD}

3.1. Historical Overview of Aluminum Hypothesis and Arguments. A link between $\mathrm{Al}$ and $\mathrm{AD}$ is supported on many fronts, beginning in 1965 with the finding of Klatzo et al. that the intracerebral administration of $\mathrm{Al}$ to experimental animals induced neurofibrillary degeneration and the appearance of tangle-like structures that were similar to the
NFTs found in the brains of AD patients [9]. Crapper et al. reported an increased level of $\mathrm{Al}$ in the brains of $\mathrm{AD}$ patients [10]. In the 1970s, Al in dialysis solutions or pharmacological compounds was found to cause dementia in dialysis patients (dialysis encephalopathy) [20]. As noted previously, several epidemiological studies reported a high percentage of $\mathrm{AD}$ cases in areas with high $\mathrm{Al}$ level in drinking water $[11,19]$.

Despite supporting evidence, the aluminum hypothesis of $\mathrm{AD}$ remains controversial and has been the subject of much debate in the past few decades. There were at least three arguments against the aluminum hypothesis. First, 


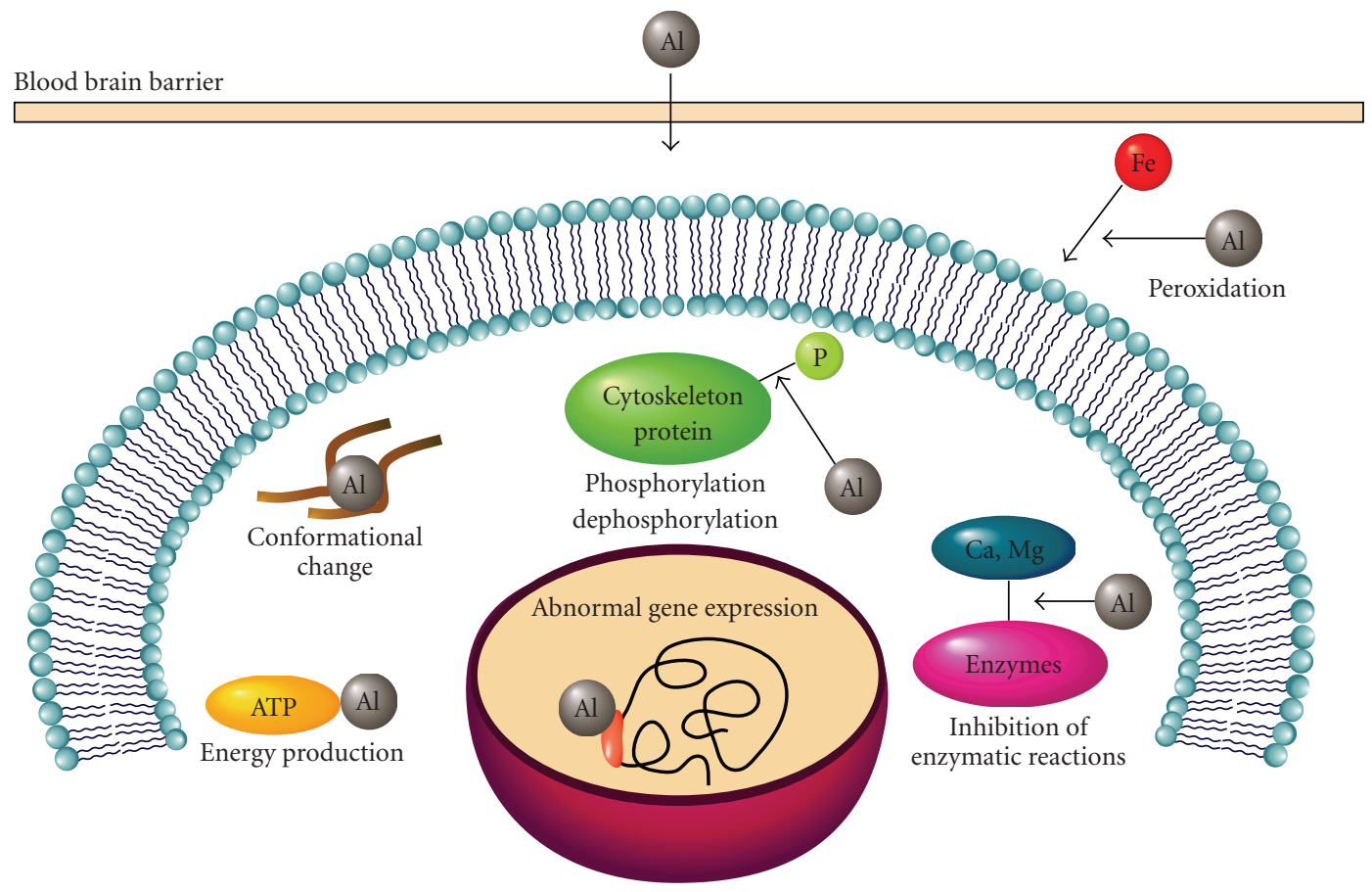

FIGURE 1: Effects of aluminum on the central nervous system. Major biological effects of $\mathrm{Al}$ on the central nervous system are depicted.

it has been argued that neurofibrillary changes in $\mathrm{Al}$ intoxicated animals (Al-NFTs) are different from those in AD patients (AD-NFTs) [108]. Arguments cite morphological and biochemical differences such as the lack of paired helical filamental (PHF) structures, their different distributions in nerve terminals, and the absence of immunoreactivity for tau protein, which is the main component of NFTs in AD patients. Second, there is no significant difference in $\mathrm{Al}$ levels of $\mathrm{AD}$ patients and age-matched controls [109]. Third, the epidemiological studies on $\mathrm{Al}$ in drinking water are immature and inconclusive [110]. However, most of these criticisms were made in the 1990s. We would like to reinvestigate these early arguments in the context of new findings in the study of AD.

Regarding the first argument, more recent immunohistochemical studies have indicated that depositions in the brains of Al-intoxicated animals are stained with the antitau antibody $[62,63]$. The accumulation of tau protein was reported in patients with dialysis encephalopathy [111], and in Al-intoxicated cultured neuronal cells [60, 61]. Al inhibits the dephosphorylation of tau [56] and enhances its aggregation in vitro [112]. Furthermore, NFTs in some AD patients have been shown to be composed of straight-type filaments rather than PHF-type filaments as is observed in Al-NFT [113]. These data indicate that attempts to discredit the aluminum hypothesis on the basis of differences between Al-NFTs and AD-NFTs are no longer tenable.

3.2. Accumulation of $A l$ in $A D$ Brain. Another argument cites a lack of significant difference between $\mathrm{Al}$ levels in $\mathrm{AD}$ patients and age-matched controls. One reason for the controversy may be $\mathrm{Al}$ contamination of the solutions used in the process of tissue fixation and staining. Therefore, prior studies in fixed tissues cannot be relied upon for precise measures of Al; quantitative analysis of nonfixed and freshly frozen tissues is necessary. One such study showed that the amount of $\mathrm{Al}$ in whole brains of $\mathrm{AD}$ patients was not significantly different in comparison to controls [114]. Landsberg et al. claimed that they could not detect $\mathrm{Al}$ in senile plaques or NFTs using nuclear microscopy [115]. However, this failure could simply be due to low detection limits of their analytical method. Bouras et al. used highly sensitive laser microprobe mass analysis (LAMMA) with nonfixed brain samples and reported an accumulation of $\mathrm{Al}$ in NFT-bearing neurons of AD brains [116]. An accumulation of $\mathrm{Al}$ in both senile plaques and NFTs has been reported in renal failure patients [117]. Recently, Yumoto et al. analyzed Al using energy-dispersive X-ray spectroscopy combined with transmission electron microscopy (TEMEDX), a method which yields a high-resolution and low detection limit. Their detailed analysis demonstrated that $\mathrm{Al}$ was present in cores of senile plaques at a concentration of 35-50 ppm [118].

\subsection{Epidemiological Studies of $A D$ and $A l$ in Drinking Water.} Some epidemiological studies have failed to demonstrate the relationship between $\mathrm{Al}$ and $\mathrm{AD}[119,120]$. However, there are a number of possible explanations for this inconsistency, particularly when considering the difficulty in making side-by-side comparisons of epidemiological studies of $\mathrm{Al}$ (e.g., intake estimations, effect of move, changes in watertreatment processes, etc.). Using strict neuropathological criteria to discriminate between $\mathrm{AD}$ patients and controls (including histopathological verification), McLachlan et al. 


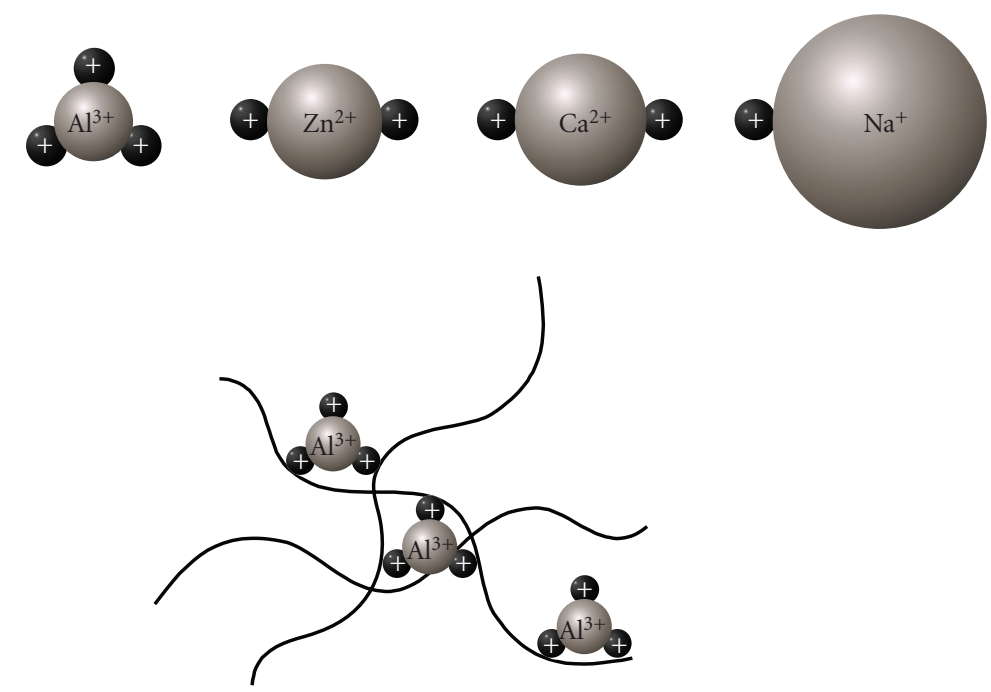

FIgURE 2: Cross-linking of protein by $\mathrm{Al}^{3+}$. $\mathrm{Al}^{3+}$ has a relatively small ionic radius $(50 \mathrm{pm})$ with 3 positive charges; here it is compared to other metal ions such as $\mathrm{Zn}^{2+}(74 \mathrm{pm}), \mathrm{Ca}^{2+}(99 \mathrm{pm})$, and $\mathrm{Na}^{+}(95 \mathrm{pm})$. These characteristics enable Al to be an effective cross-linker of proteins.

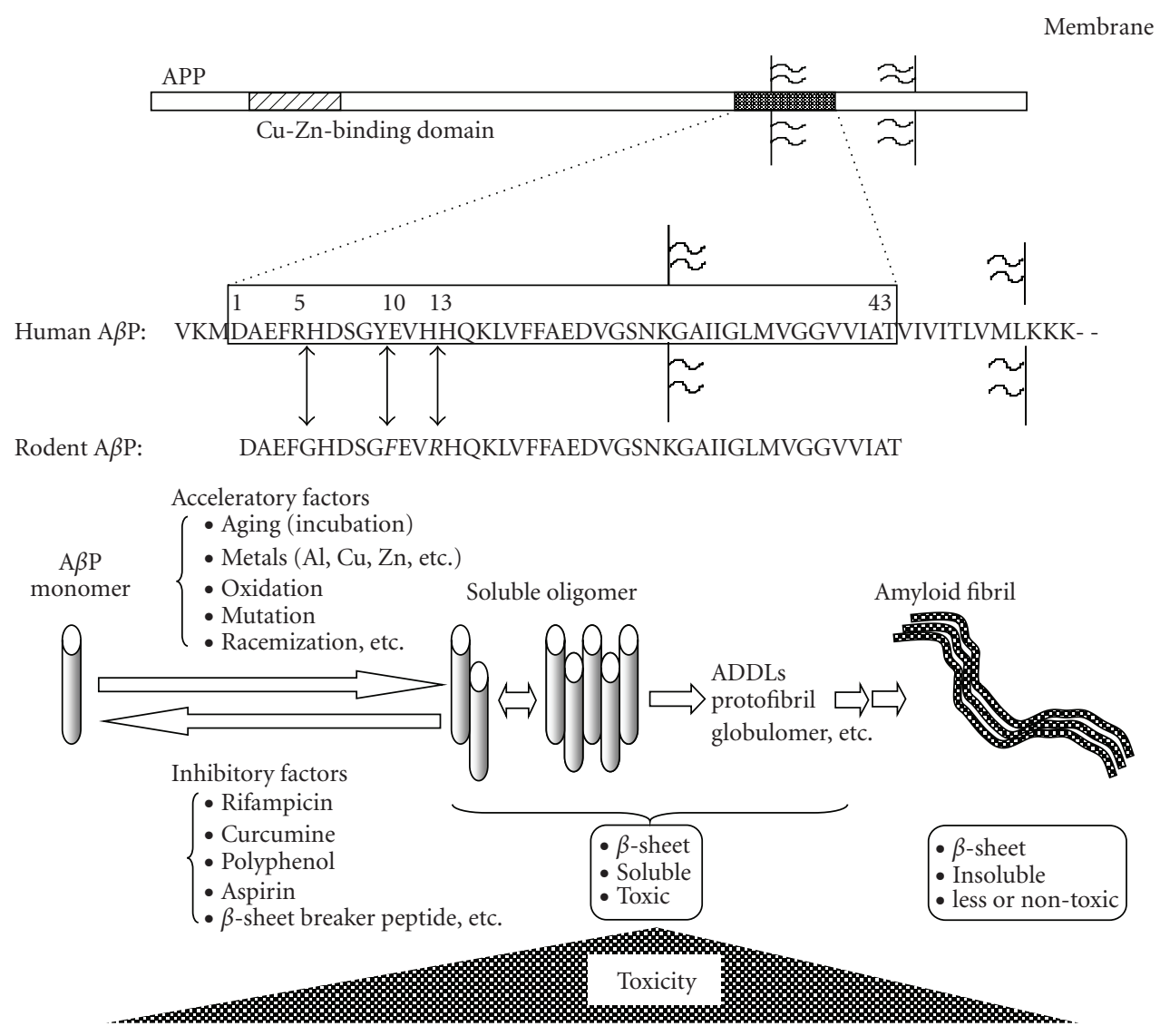

FIgURE 3: Secretion of A $\beta$ P from APP and its oligomerization. A $\beta$ P is secreted by the cleavage of the APP N-terminus by $\beta$-secretase (BACE), followed by the intramembrane cleavage of the C-terminus by $\gamma$-secretase. APP also binds to $\mathrm{Cu}$ or $\mathrm{Zn}$. Human A $\beta \mathrm{P}$ and rodent $\mathrm{A} \beta \mathrm{P}$ differ by 3 amino acids $\left(\mathrm{Arg}^{5}, \mathrm{Tyr}^{10}\right.$, and $\left.\mathrm{His}^{13}\right)$. A $\beta$ P monomers form random-coil structures. However, under aging conditions or the existence of trace metals such as $\mathrm{Al}, \mathrm{Zn}$, and $\mathrm{Cu}, \mathrm{A} \beta \mathrm{P}$ self-aggregates and oligomerizes (dimmer to protofibrils), and then forms insoluble amyloid fibrils. Although monomeric A $\beta$ Ps are not toxic, oligomeric $A \beta P$ s induce marked neuronal death. 

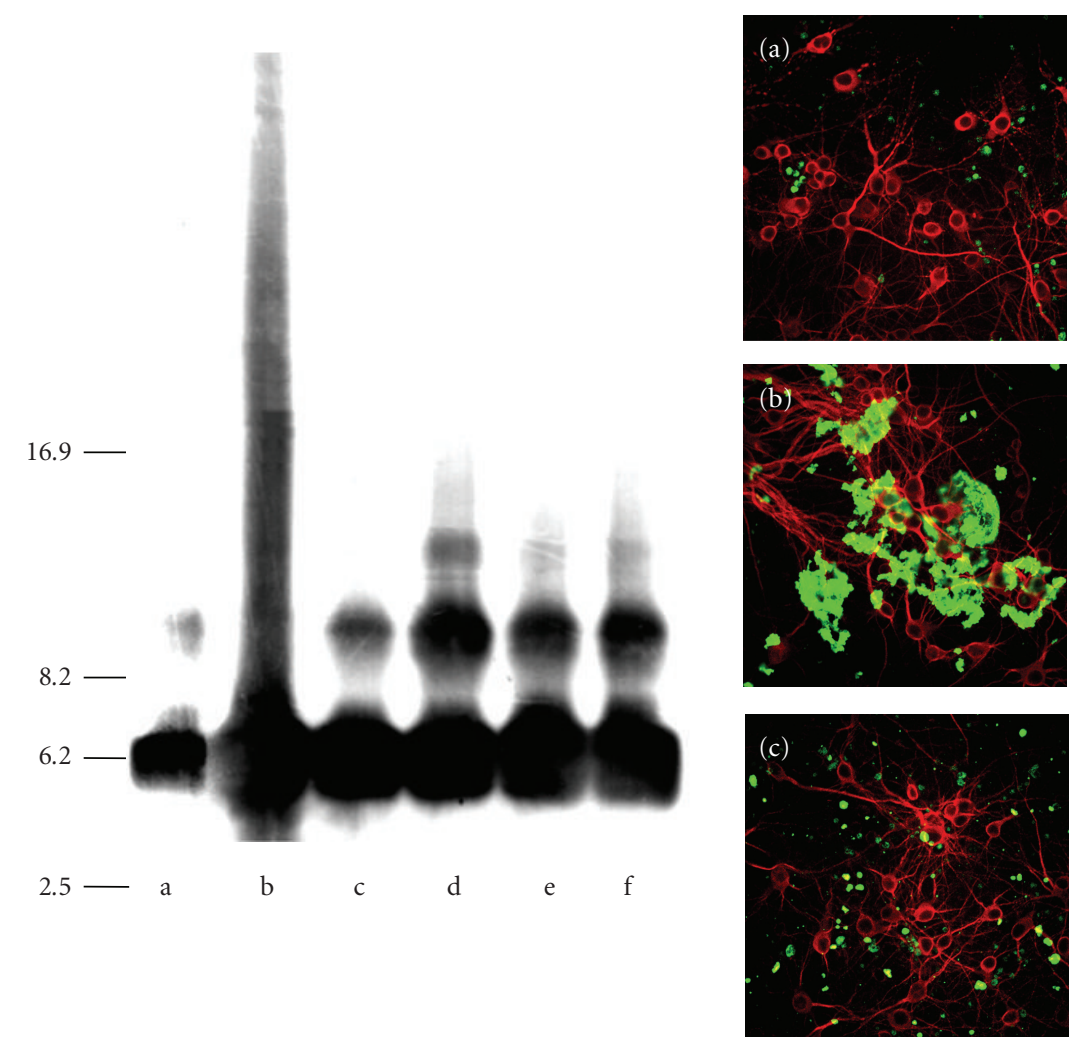

(A)

(B)

Figure 4: Aggregation of $\mathrm{A} \beta \mathrm{P}$ by $\mathrm{Al}$ and other metals. (A) Immunoblotting of $\mathrm{A} \beta \mathrm{P}$ preincubated with $\mathrm{Al}$ and other metals. The solutions of $\mathrm{A} \beta \mathrm{P}(1-40)$ were incubated at $37^{\circ} \mathrm{C}$ for $24 \mathrm{~h}$ with or without $1 \mathrm{mM}$ of various metals, and were analyzed by SDS-PAGE and immunoblotting using an antibody to $\mathrm{A} \beta \mathrm{P}$. Each lane contained $4 \mu \mathrm{g} \mathrm{A} \beta \mathrm{P}(1-40)$. Lane a: control, b: $\mathrm{AlCl}_{3}, \mathrm{c}: \mathrm{ZnCl}_{2}, \mathrm{~d}: \mathrm{CuCl}_{2}, \mathrm{e}: \mathrm{FeCl}_{3}, \mathrm{f}: \mathrm{CdCl}_{2}, \mathrm{Modified} \mathrm{from}$ [134]. (B) Deposition of $\mathrm{A} \beta \mathrm{P}$ on surfaces of cultured neurons. Solutions of $\mathrm{A} \beta \mathrm{P}(1-40)$ preincubated at $37^{\circ} \mathrm{C}$ for $24 \mathrm{~h}(\mathrm{a})$, with $1 \mathrm{mM} \mathrm{AlCl} \mathrm{m}_{3}$ (b), or $1 \mathrm{mM} \mathrm{ZnCl}_{2}$ (c) were applied to cultured rat cortical neurons. After 2 days of exposure, cells were washed and double immunostained with a polyclonal antibody to A $\beta$ P (green) and a monoclonal antibody to MAP2 (red), and observed by laser confocal microscope. Scale bar: $50 \mu \mathrm{m}$, modified from [64].

found an elevated risk of histopathologically verified AD to be associated with the consumption of higher concentrations of $\mathrm{Al}$ in drinking water [121]. More detailed analysis revealed an association between exposure to organic monomeric $\mathrm{Al}$ and $\mathrm{AD}$, even after adjustment for education level, family history and presence of the apoE4 allele [122].

The amount of $\mathrm{Al}$ consumed in drinking water is approximately $5 \%$ of the total daily intake. Thus, it is possible that some factors that prevent or accelerate $\mathrm{Al}$ absorption may exist in drinking water. Silicate in the water was reported to interact with $\mathrm{Al}$ and prevent $\mathrm{Al}$ toxicity to fish [123, 124]. Therefore, the level of silicate in drinking water may also be important. In a French cohort study, the relationship between $\mathrm{Al}$ and cognitive impairment is suggested to be influenced by the silica concentration [29]. Cognitive impairment among women was correlated with low concentrations of silica in drinking water [125].

In considering the above new lines of evidence about the neurotoxicity and epidemiology of $\mathrm{Al}$, it is difficult to agree with the early criticisms of the aluminum hypothesis.
3.4. Effects of $A l$ on the Oligomerization of $A \beta P$. In the 1990 s when the early arguments were claimed, Al-induced Alzheimer-like pathological changes were first attributed to tau proteins (NFT). However, numerous biochemical, toxicological, cell biological, and genetic studies have supported the "amyloid cascade hypothesis", namely, that the accumulation of $\mathrm{A} \beta \mathrm{P}$ and its neurotoxicity play a central role in the pathogenesis of $\mathrm{AD}[12,13]$.

$\mathrm{A} \beta \mathrm{P}$ is a small peptide of $39-43$ amino acid residues, secreted by cleavage of the amyloid precursor protein (APP) $N$-terminus by $\beta$-APP cleaving enzyme (BACE) and intramembrane cleavage of its C-terminus by $\gamma$-secretase. Genetic studies of early-onset cases of familial AD indicated that APP mutations and A $\beta$ P metabolism are associated with $\mathrm{AD}$ [126]. Yankner et al. reported that the first 40 amino acid residues of $\mathrm{A} \beta \mathrm{P}(\mathrm{A} \beta \mathrm{P}(1-40))$ caused the death of cultured rat hippocampal neurons or neurodegeneration in the brains of experimental animals [127]. A $\beta \mathrm{P}$ is a hydrophobic peptide with an intrinsic tendency to self-assemble and form SDSstable oligomers in aqueous solution. The monomeric form 


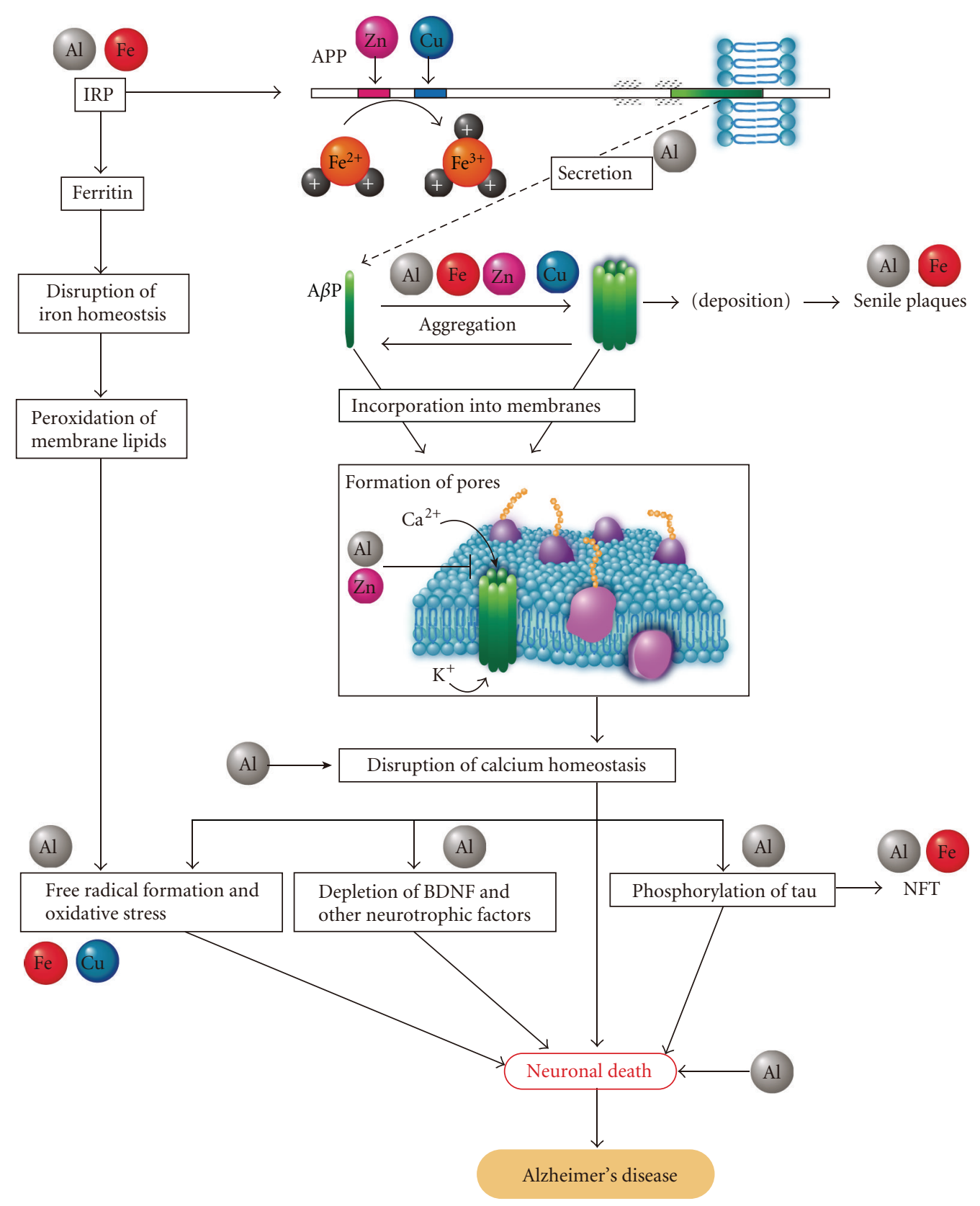

FIGURE 5: Modified aluminum hypothesis addressing the implications of Al and other trace metals in the pathogenesis of Alzheimer's disease. This model describes the implication of $\mathrm{Al}$ and other trace metals including $\mathrm{Fe}, \mathrm{Cu}$, and $\mathrm{Zn}$ in APP processing, generation and oligomerization of $\mathrm{A} \beta \mathrm{P}$, and the neurotoxic effects caused by $\mathrm{A} \beta \mathrm{P}$. Details are descried in the text.

of $\mathrm{A} \beta \mathrm{P}$ has a random coiled structure. Oligomeric $\mathrm{A} \beta \mathrm{Ps}$ have $\beta$-pleated sheet structures and form insoluble aggregates, termed amyloid fibrils. Neurotoxicity of $\mathrm{A} \beta \mathrm{P}(1-40)$ peptides was enhanced by the process of "aging" (aggregated under incubation at $37^{\circ} \mathrm{C}$ for several days) compared to freshly prepared $\mathrm{A} \beta \mathrm{P}(1-40)$ in cultured neurons [128], and were correlated with its $\beta$-sheet contents [129]. Recent approaches using size-exclusion chromatography, gel electrophoresis, and atomic force microscopy have demonstrated that the soluble oligomers are synaptotoxic and neurotoxic [130]. Figure 3 exhibits the oligomerization of $\mathrm{A} \beta \mathrm{P}$ and its neurotoxicity.

Considering that $\mathrm{A} \beta \mathrm{P}$ is secreted in the cerebrospinal fluid (CSF) of young individuals as well as in aged or dementia patients [146], factors that accelerate or inhibit oligomerization may play essential roles in the pathogenesis 
TABLE 2: Al-induced conformational changes of various proteins.

\begin{tabular}{|c|c|}
\hline Proteins & References \\
\hline \multicolumn{2}{|l|}{$\begin{array}{l}\text { Disease-related proteins } \\
\text {. }\end{array}$} \\
\hline \multicolumn{2}{|l|}{ Alzheimer's disease } \\
\hline $\mathrm{A} \beta \mathrm{P}(1-40)$ & {$[64,131-134]$} \\
\hline \multicolumn{2}{|l|}{ DAEFRHDSGYEVHHQKLVFFAEDVGSNKGAIIGLMVGGVV } \\
\hline $\mathrm{A} \beta \mathrm{P}(1-42):$ & {$[135,136]$} \\
\hline \multicolumn{2}{|l|}{ DAEFRHDSGYEVHHQKLVFFAEDVGSNKGAIIGLMVGGVVIA } \\
\hline $\mathrm{A} \beta \mathrm{P}(25-35):$ & [137] \\
\hline \multicolumn{2}{|l|}{ GSNKGAIIGLMV } \\
\hline APP & [138] \\
\hline Tau or hyperphosphorylated tau (PHF-tau) & {$[32,57,139]$} \\
\hline \multicolumn{2}{|l|}{ Perkinson's disease and other diseases with Lewy body } \\
\hline$\alpha$-synuclein (NACP) & {$[140,141]$} \\
\hline \multicolumn{2}{|l|}{ Type 2 diabetes mellitus } \\
\hline Amylin: & [142] \\
\hline \multicolumn{2}{|l|}{ KCNTATCATQRLANFLVHSSNNFGAILSSTNVGSNTY } \\
\hline \multicolumn{2}{|l|}{ Familial British dementia } \\
\hline ABri: & [143] \\
\hline \multicolumn{2}{|l|}{ ASNCPAIRHPGNKPAVGTLICSRTVKKNIIGGN } \\
\hline \multicolumn{2}{|l|}{ Spinocerebellar ataxia } \\
\hline Ataxin 3 & [144] \\
\hline \multicolumn{2}{|l|}{ Dialysis-related arthropathy } \\
\hline$\beta_{2}$-microglobulin & [145] \\
\hline
\end{tabular}

of AD. Several factors such as peptide concentration, $\mathrm{pH}$ or composition of solvents, and temperature can influence the oligomerization processes [147].

Interestingly, rodent $\mathrm{A} \beta \mathrm{P}$ exhibits less tendency to oligomerization than human $\mathrm{A} \beta \mathrm{P}$ in vitro [148] and the accumulation of $\mathrm{A} \beta \mathrm{P}$ is rarely observed in the brains of rodents (rats or mice) as compared to primates (humans or monkeys). As shown in Figure 3, the amino acid sequences of human and rodent $\mathrm{A} \beta \mathrm{P}$ are similar, but rodent $\mathrm{A} \beta \mathrm{P}$ differs from primate only 3 amino acids $\left(\mathrm{Arg}^{5}, \mathrm{Tyr}^{10}\right.$, and $\mathrm{His}^{13}$ ) from primate $\mathrm{A} \beta \mathrm{P}$. All 3 amino acids have the ability to bind metals. Therefore, trace elements including $\mathrm{Al}^{3+}$ are of particular interest as potential acceleratory factors and may play important roles in the accumulation of $\mathrm{A} \beta \mathrm{P}$ in the human brain.

Table 2 summarizes the effects of $\mathrm{Al}^{3+}$ on conformational changes of $\mathrm{A} \beta \mathrm{P}$ and other various disease-related proteins. Exley et al. first demonstrated by $\mathrm{CD}$ spectroscopy that $\mathrm{Al}$ induces a conformational change in $\mathrm{A} \beta \mathrm{P}(1-40)$ [131]. Al has also been shown to promote the aggregation of ${ }^{125}$ I-labelled $\mathrm{A} \beta \mathrm{P}(1-40)$, with similar findings for $\mathrm{Fe}$ and $\mathrm{Zn}$ [132]. Bush et al. demonstrated that $\mathrm{Zn}^{2+}$ and $\mathrm{Cu}^{2+}$ caused the oligomerization of $\mathrm{A} \beta \mathrm{P}[149,150]$. However, role of $\mathrm{Zn}^{2+}$ in $\mathrm{AD}$ is complex and enigmatic. Lovell et al. reported that zinc has the protective effects against $\mathrm{A} \beta \mathrm{P}$-induced neurotoxicity [151]. We have demonstrated that $\mathrm{Zn}^{2+}$ blocks $\mathrm{A} \beta \mathrm{P}$-channels formed on membranes and inhibits the neurotoxicity [152].

We have developed a system for investigating $A \beta P$ oligomerization that involves immunoblotting and precipitation. Using this system, we have demonstrated that
$\mathrm{Al}$ enhances the polymerization of $\mathrm{A} \beta \mathrm{P}(1-40)$ and forms SDS-stable oligomers in vitro $[64,133,134]$. The aggregated $\mathrm{A} \beta \mathrm{P}(1-40)$ is redissolved by adding deferoxamine (DFO), an $\mathrm{Al}$ chelator. The oligomerization induced by $\mathrm{Al}$ is more marked than that induced by other metals, including $\mathrm{Zn}^{2+}$, $\mathrm{Fe}^{3+}, \mathrm{Cu}^{2+}$, and $\mathrm{Cd}^{2+}$ (Figure 4(A)). Furthermore, while Alaggregated $\mathrm{A} \beta \mathrm{Ps}$ bind tightly to the surface of cultured neurons and form fibrillar deposits, $\mathrm{Zn}$-aggregated $\mathrm{A} \beta \mathrm{Ps}$ are rarely observed on the surface of cultured neurons (Figure 4(B)). These results suggest that $\mathrm{Al}$-aggregated A $\beta$ Ps have a strong affinity for membrane surfaces as a result of minimal degradation by proteases. Indeed, $\mathrm{Al}$ has been shown to inhibit the degradation of $\mathrm{A} \beta \mathrm{P}$ as the result of conformational changes $[43,153]$. Furthermore, $A \beta P$ coupled with $\mathrm{Al}$ is more toxic than normal $\mathrm{A} \beta \mathrm{P}$ causing membrane disruption or perturbation of neural $\mathrm{Ca}^{2+}$ homeostasis and mitochondrial respiration [154-156].

The chronic application of $\mathrm{Al}$ caused the accumulation of $\mathrm{A} \beta \mathrm{P}$ in cultured neurons of rat cerebral cortex [64] and in neuroblastoma cells [65]. Praticó et al. (2002) found that orally administered $\mathrm{Al}$ caused a marked increase in the amount of $\mathrm{A} \beta \mathrm{P}$ both in its secreted and accumulated forms, and increased deposition of senile plaques in $\mathrm{AD}$-model mice transfected with the human APP gene ( $\operatorname{Tg} 2576)$ [66]. These results are consistent with other studies demonstrating that oral $\mathrm{Al}$ exposure causes the accumulation of $\mathrm{A} \beta \mathrm{P}$ and impairs spatial learning memory in $\mathrm{AD}$-model mice [67].

Exposure to $\mathrm{Al}$ causes the accumulation of $\mathrm{A} \beta \mathrm{P}$ and induces adverse effects in humans as seen in the aftermath of the accidental Al exposure in 1988 at Camelford [157]. The 
neuropathological case study of a 58 year-old woman who was exposed to $\mathrm{Al}$ and died 15 years later with unspecified neurological symptoms demonstrated the rare form of sporadic cerebral amyloid angiopathy, which is characterized by the deposition of $\mathrm{A} \beta \mathrm{P}$ in blood vessels and has a causative link with AD [158]. The deposition of high amounts of $\mathrm{Al}$ in the patient's brain was also observed.

$\mathrm{Al}$ has also been reported to bind and cause conformational changes in other AD-related proteins, including APP [138], tau protein [32, 57], and PHF-tau protein [139] and in proteins related to other neurodegenerative diseases such as $\alpha$-synuclein (Parkinson's disease (PD) and dementia with Lewy bodies; DLB) [140, 141], amylin (diabetes mellitus) [142], ABri (familial British dementia) [143], and ataxin 3 (spinocerebellar ataxia type 3) [144], $\beta_{2}$-microglobulin (dialysis-related arthropathy) [145] (Table 2).

3.5. Metal-Metal Interactions in the Pathogenesis of AD. The evidence now suggests that the significance of $\mathrm{Al}$ in the pathogenesis of AD should be concerned. Other metals usually share the binding site of one metal ion, although their binding constants differ. Al binds to various metal-binding proteins and influences metal homeostasis. The interactions between $\mathrm{Al}$ and other metals should be considered owing to the implications of various trace elements in the pathogenesis of AD. Figure 5 illustrates the modified aluminum hypothesis that accounts for the implications of $\mathrm{Al}$ and other trace metals in $\mathrm{AD}$ pathology from the secretion of $\mathrm{A} \beta \mathrm{P}$ to its neurotoxicity as mentioned below.

3.5.1. $\mathrm{Al}^{3+}$ Affects Iron-Homeostasis and Generates Free Radicals. Al has similar characteristics to iron $(\mathrm{Fe})$ and binds to Fe-binding proteins such as ferritin, transferrin, iron regulatory protein (IRP) or to iron chelators such as DFO. The iron responsive element/iron regulatory protein (IRE/IRP) network regulates the production of iron binding proteins which prevent the formation of free $\mathrm{Fe}^{2+}$, which causes toxic free radicals [159]. In iron-deficient conditions, IRP binds to IRE and regulates the expression of genes that contain IREs in their mRNA, such as ferritin or transferrin. As the concentration of free $\mathrm{Fe}^{2+}$ increases, the binding of iron to IRP, expression of transferrin is downregulated and that of ferritin is upregulated, and the amount of free $\mathrm{Fe}^{2+}$ is thereby decreased. $\mathrm{Al}^{3+}$ also binds to IRP [34, 160], and thus influences the expression of Fe-binding proteins with IREs in their mRNA causing an elevated Fe concentration [161]. Al also influences the uptake of iron into cultured neurons or glial cells $[34,162]$. Thus, $\mathrm{Al}^{3+}$ affects iron homeostasis and the expression of various iron-regulated proteins with IREs. Important findings are that APP mRNA contains an IRE as well as ferritin, and its expression is regulated by iron [163]. Indeed, $\mathrm{Al}$ caused elevated expression of APP in experimental animals [40, 41]. Recently, Duce et al. demonstrated that APP has ferroxidase activity, which converts $\mathrm{Fe}^{2+}$ to $\mathrm{Fe}^{3+}$ and regulates free pro-oxidant $\mathrm{Fe}^{2+}$ concentrations [164]. They also found that $\mathrm{Zn}^{2+}$ inhibits the ferroxidase activity of APP. APP also possesses copper/zinc binding sites in its amino-terminal domain and in the $\mathrm{A} \beta \mathrm{P}$ domain and may be involved in homeostasis of these metals [165]. $\mathrm{Al}^{3+}$ stimulates Fe-induced membrane lipid peroxidation and causes oxidative damage in vitro and in vivo, although $\mathrm{Al}^{3+}$ does not directly affect peroxidation $[89,90]$. There are other important findings implicating iron homeostasis in $\mathrm{AD}$ pathogenesis. Iron related genes such as transferrin $\mathrm{C} 2$ or hemochromatosis were revealed to be risk factors for $\mathrm{AD}$ [166, 167]. Imagawa et al. (1992) reported that iron supplementation was effective for the recovery of cognitive functions in $\mathrm{AD}$ patients [168].

3.5.2. $\mathrm{Al}^{3+}$ and Other Metals Enhance the Oligomerization of $A \beta P$. An abnormal expression of APP could lead to an increased secretion of $\mathrm{A} \beta \mathrm{P}$, and then enhance its accumulation. Secreted $\mathrm{A} \beta \mathrm{P}$ is usually degraded by various proteases such as neprilysin within a short period. The downregulation of neprilysin induced by $\mathrm{Al}$ can cause the accumulation $\mathrm{A} \beta \mathrm{P}[43]$. Furthermore, $\mathrm{A} \beta \mathrm{P}$ becomes oligomerized in the presence of trace metals such as $\mathrm{Al}^{3+}, \mathrm{Zn}^{2+}, \mathrm{Fe}^{3+}$, and $\mathrm{Cu}^{2+}$, could be resistant to proteases, and thus accumulates in the brain.

3.5.3. $\mathrm{Al}^{3+}$ Impairs Calcium Homeostasis. A $\beta \mathrm{P}$ oligomers could be readily incorporated into cell membranes, resulting in the formation of ion channels [147]. A subsequent influx of $\mathrm{Ca}^{2+}$ through these amyloid channels would lead to the phosphorylation of tau, depletion of neurotrophic factors, and the formation of free radicals, and so forth, with the outcome of these effects being neuronal death. $\mathrm{Al}^{3+}$ blocks various $\mathrm{Ca}^{2+}$ channels and influences $\mathrm{Ca}^{2+}$ homeostasis. We found that $\mathrm{Al}$ also inhibits the increase in $\mathrm{Ca}^{2+}$ levels induced by brain-derived neurotrophic factor (BDNF) [94]. As described previously, $\mathrm{Al}$ is implicated in most of these neurodegenerative pathways such as dephosphorylation of tau [56], depletion of neurotrophic factor [38], formation of free radicals [89], and induction of neuronal death.

This working hypothesis may be useful in developing an understanding of the link between $\mathrm{AD}$ and trace elements including $\mathrm{Al}, \mathrm{Zn}, \mathrm{Cu}$, and $\mathrm{Fe}$. Considering the implications of metals in $\mathrm{AD}$ pathogenesis, chelation therapy for $\mathrm{AD}$ treatment is of great interest [169]. Clioquinol (quinoform), a chelator of $\mathrm{Cu}^{2+}$ or $\mathrm{Zn}^{2+}$, inhibits oligomerization of $\mathrm{A} \beta \mathrm{P}$ and attenuates the accumulation of amyloid in the brains of experimental animals. Clinical trials using its analogue PBT2 are under investigation [170]. DFO, a chelator of $\mathrm{Al}$ and $\mathrm{Fe}$, attenuates the decline of daily living skills in $\mathrm{AD}$ patients [171]. Silicates, which couple with $\mathrm{Al}$ and reduce its toxicity, are also candidates for chelation therapy in $\mathrm{AD}$ [172].

\section{Conclusion: Al and Human Health}

In this review, we have summarized the properties associated with various aspects of $\mathrm{Al}$ neurotoxicity. There is growing evidence for a link between $\mathrm{Al}$ and $\mathrm{AD}$, and between other metals and AD. Nevertheless, because the precise mechanism of $\mathrm{AD}$ pathogenesis remains unknown, this issue is controversial. However, it is widely accepted that $\mathrm{Al}$ is a recognized neurotoxin, and that it could cause cognitive deficiency 
and dementia when it enters the brain and may have various adverse effects on CNS. In general, the absorption of metals by the gastrointestinal tract is widely variable and is influenced by various factors including an individual difference, age, $\mathrm{pH}$, stomach contents [173]. Recent studies using mass spectrometry of ${ }^{26} \mathrm{Al}$ have demonstrated that small, but a considerable amount of $\mathrm{Al}$ crosses the blood brain barrier, enters into the brain, and accumulates in a semipermanent manner [174, 175]. Therefore, $\mathrm{Al}$ can cause severe health problems in particular populations, including infants, elderly people, and patients with impaired renal functions, and unnecessary exposure to $\mathrm{Al}$ should be avoided for such patients [176].

In 1989, a joint FAO/WHO Expert Committee on Food Additives (JECFA) recommended a provisional tolerable weekly intake (PTWI) of $7.0 \mathrm{mg} / \mathrm{kg}$ body weight $\mathrm{Al}$; however, this was changed in 2007 to $1.0 \mathrm{mg} / \mathrm{kg}$ body weight because of potential effects on the reproductive system and the developing nervous system. The characteristics of Al neurotoxity are complex, and further research is needed especially in relation to bioavailability, cellular effects, metabolism, and metal-metal interactions.

\section{Abbreviations}

$\begin{array}{ll}\text { AD: } & \text { Alzheimer's disease } \\ \text { A } \beta \text { P: } & \beta \text {-amyloid protein } \\ \text { Al: } & \text { Aluminum } \\ \text { ALS: } & \text { Amyotrophic lateral sclerosis } \\ \text { APP: } & \text { Amyloid precursor protein } \\ \text { BACE: } & \beta \text {-APP cleaving enzyme } \\ \text { BDNF: } & \text { Brain derived neurotrophic factor } \\ \text { CSF: } & \text { Cerebrospinal fluid } \\ \text { CNS: } & \text { Central nervous system } \\ \text { DFO: } & \text { Deferoxamine } \\ \text { DLB: } & \text { Dementia with Lewy bodies } \\ \text { JECFA: } & \text { FAO/WHO Expert Committee on Food } \\ & \text { Additives } \\ \text { IRE: } & \text { Iron responsive element } \\ \text { IRP: } & \text { Iron regulatory protein } \\ \text { LAMMA: } & \text { Laser microprobe mass analysis } \\ \text { LTP: } & \text { Long-term potentiation } \\ \text { MAP: } & \text { Microtubule-associated protein } \\ \text { NFT: } & \text { Neurofibrillary tangle } \\ \text { NGF: } & \text { Nerve growth factor } \\ \text { PD: } & \text { Parkinson's disease } \\ \text { PHF: } & \text { Paired helical filament }\end{array}$

PTWI: Provisional tolerable weekly intake TEM-EDX: Energy-dispersive X-ray spectroscopy combined with transmission electron microscopy.

\section{Acknowledgments}

This work was partially supported by a Grant-in-Aid for Scientific Research from the Ministry of Education, Culture, Sports, Science and Technology of Japan and by a Grant from Cooperation for Innovative Technology and
Advanced Research in Evolutional Area (CITY AREA) from the Miyazaki Prefectural Industrial Support Foundation.

\section{References}

[1] H. Shiraki and Y. Yase, "Amyotrophic lateral sclerosis and Parkinsonism-dementia in the Kii peninsula: comparison with the same disorders in Guam and with Alzheimer's disease," Handbook of Clinical Neurology, vol. 15, pp. 273300, 1991.

[2] M. S. Petrik, M. C. Wong, R. C. Tabata, R. F. Garry, and C. A. Shaw, "Aluminum adjuvant linked to Gulf War illness induces motor neuron death in mice," NeuroMolecular Medicine, vol. 9, no. 1, pp. 83-100, 2007.

[3] A. Campbell, "The potential role of aluminium in Alzheimer's disease," Nephrology Dialysis Transplantation, vol. 17, no. 2, pp. 17-20, 2002.

[4] D. R. McLachlan, "Aluminium and the risk for Alzheimer's disease," Environmetrics, vol. 6, no. 3, pp. 233-275, 1995.

[5] P. Zatta, Ed., "Recent topics in aluminium chemistry," Coordination Chemistry Reviews, vol. 228, no. 2, 2002.

[6] M. Kawahara, "Effects of aluminum on the nervous system and its possible link with neurodegenerative diseases," Journal of Alzheimer's Disease, vol. 8, no. 2, pp. 171-182, 2005.

[7] P. Zatta, R. Lucchini, S. J. van Rensburg, and A. Taylor, “The role of metals in neurodegenerative processes: aluminum, manganese, and zinc," Brain Research Bulletin, vol. 62, no. 1, pp. 15-28, 2003.

[8] D. J. Selkoe, "The molecular pathology of Alzheimer's disease," Neuron, vol. 6, no. 4, pp. 487-498, 1991.

[9] I. Klatzo, H. Wisniewski, and E. Streicher, "Experimental production of neurofibrillary degeneration I. Light microscopic observation," Journal of Neuropathology \& Experimental Neurology, vol. 24, pp. 187-199, 1965.

[10] D. R. Crapper, S. S. Krishnan, and A. J. Dalton, "Brain aluminum distribution in Alzheimer's disease and experimental neurofibrillary degeneration," Science, vol. 180, no. 4085, pp. 511-513, 1973.

[11] C. N. Martyn, C. Osmond, J. A. Edwardson, D. J. P. Barker, E. C. Harris, and R. F. Lacey, "Geographical relation between Alzheimer's disease and aluminium in drinking water," The Lancet, vol. 1, no. 8629, pp. 59-62, 1989.

[12] J. Hardy and D. J. Selkoe, "The amyloid hypothesis of Alzheimer's disease: progress and problems on the road to therapeutics," Science, vol. 297, no. 5580, pp. 353-356, 2002.

[13] O. Wirths, G. Multhaup, and T. A. Bayer, "A modified $\beta$ amyloid hypothesis: intraneuronal accumulation of the $\beta$ amyloid peptide - the first step of a fatal cascade," Journal of Neurochemistry, vol. 91, no. 3, pp. 513-520, 2004.

[14] S. L. Sensi, P. Paoletti, A. I. Bush, and I. Sekler, "Zinc in the physiology and pathology of the CNS," Nature Reviews Neuroscience, vol. 10, no. 11, pp. 780-791, 2009.

[15] P. Zatta, D. Drago, S. Bolognin, and S. L. Sensi, "Alzheimer's disease, metal ions and metal homeostatic therapy," Trends in Pharmacological Sciences, vol. 30, no. 7, pp. 346-355, 2009.

[16] Y. H. Hung, A. I. Bush, and R. A. Cherny, "Copper in the brain and Alzheimer's disease," Journal of Biological Inorganic Chemistry, vol. 15, no. 1, pp. 61-76, 2010.

[17] J. Spofforth, 1. R. C. Edin, and M. R. C. Eng, "Case of aluminium poisoning," The Lancet, vol. 197, no. 5103, p. 1301, 1921. 
[18] J. G. Chusid, B. L. Pacella, L. M. Kopeloff, and N. Kopeloff, "Chronic epilepsy in the monkey following multiple intracerebral injection of alumina cream," Proceedings of the Society for Experimental Biology and Medicine, vol. 78, pp. 53-54, 1951.

[19] M. R. Wills and J. Savory, "Aluminum and chronic renal failure: sources, absorption, transport, and toxicity," Critical Reviews in Clinical Laboratory Sciences, vol. 27, no. 1, pp. 59107, 1989.

[20] A. C. Alfrey, G. R. LeGendre, and D. Kaehny, "The dialysis encephalopathy syndrome. Possible aluminium intoxication," The New England Journal of Medicine, vol. 294, no. 4, pp. 184-188, 1976.

[21] P. Altmann, J. Cunningham, U. Dhanesha, M. Ballard, J. Thompson, and F. Marsh, "Disturbance of cerebral function in people exposed to drinking water contaminated with aluminium sulphate: retrospective study of the Camelford water incident," British Medical Journal, vol. 319, no. 7213, pp. 807-811, 1999.

[22] T. P. Flaten, "Aluminium as a risk factor in Alzheimer's disease, with emphasis on drinking water," Brain Research Bulletin, vol. 55, no. 2, pp. 187-196, 2001.

[23] M. F. Frecker, "Dementia in Newfoundland: identification of a geographical isolate?" Journal of Epidemiology and Community Health, vol. 45, no. 4, pp. 307-311, 1991.

[24] L. C. Neri and D. Hewitt, "Aluminium, Alzheimer's disease, and drinking water," The Lancet, vol. 338, no. 8763, p. 390, 1991.

[25] W. F. Forbes and D. R. C. McLachlan, "Further thoughts on the aluminum-Alzheimer's disease link," Journal of Epidemiology and Community Health, vol. 50, no. 4, pp. 401403, 1996.

[26] H. Jacqmin, D. Commenges, L. Letenneur, P. BarbergerGateau, and J. F. Dartigues, "Components of drinking water and risk of cognitive impairment in the elderly," American Journal of Epidemiology, vol. 139, no. 1, pp. 48-57, 1994.

[27] V. Rondeau, D. Commenges, H. Jacqmin-Gadda, and J. F. Dartigues, "Relation between aluminum concentrations in drinking water and Alzheimer's disease: an 8-year follow-up study," American Journal of Epidemiology, vol. 152, no. 1, pp. 59-66, 2000.

[28] V. Rondeau, H. Jacqmin-Gadda, D. Commenges, C. Helmer, and J. F. Dartigues, "Aluminum and silica in drinking water and the risk of Alzheimer's disease or cognitive decline: findings from 15-year follow-up of the PAQUID cohort," American Journal of Epidemiology, vol. 169, no. 4, pp. 489496, 2009.

[29] W. J. Lukiw, T. P. A. Kruck, and D. R. Crapper McLachlan, "Alterations in human linker histone-DNA binding in the presence of aluminum salts in vitro and in Alzheimer's disease," NeuroToxicology, vol. 8, no. 2, pp. 291-301, 1987.

[30] K. S. Bharathi, R. Jagannatha, and R. Stein, "First evidence on induced topological changes in supercoiled DNA by an aluminium D-aspartate complex," Journal of Biological Inorganic Chemistry, vol. 8, no. 8, pp. 823-830, 2003.

[31] K. S. Latha, S. Anitha, K. S. J. Rao, and M. A. Viswamitra, "Molecular understanding of aluminum-induced topological changes in (CCG) 12 triplet repeats: relevance to neurological disorders," Biochimica et Biophysica Acta, vol. 1588, no. 1, pp. 56-64, 2002.

[32] N. A. Muma and S. M. Singer, "Aluminum-induced neuropathology: transient changes in microtubule-associated proteins," Neurotoxicology and Teratology, vol. 18, no. 6, pp. 679-690, 1996.

[33] I. M. Parhad, C. A. Krekoski, A. Mathew, and P. M. Tran, "Neuronal gene expression in aluminum myelopathy," Cellular and Molecular Neurobiology, vol. 9, no. 1, pp. 123138, 1989.

[34] S. Oshiro, M. Kawahara, S. Mika et al., "Aluminum taken up by transferrin-independent iron uptake affects the iron metabolism in rat cortical cells," Journal of Biochemistry, vol. 123, no. 1, pp. 42-46, 1998.

[35] W. J. Lukiw, H. J. LeBlanc, L. A. Carver, D. R. C. McLachlan, and N. G. Bazan, "Run-on gene transcription in human neocortical nuclei: inhibition by nanomolar aluminum and implications for neurodegenerative disease," Journal of Molecular Neuroscience, vol. 11, no. 1, pp. 67-78, 1998.

[36] F. Bosetti, G. Solaini, E. A. Tendi, E. G. Chikhale, K. Chandrasekaran, and S. I. Rapoport, "Mitochondrial cytochrome c oxidase subunit III is selectively down-regulated by aluminum exposure in PC12S cells," NeuroReport, vol. 12, no. 4, pp. 721-724, 2001.

[37] K. A. Cox and M. A. Dunn, "Aluminum toxicity alters the regulation of calbindin-D28k protein and mRNA expression in chick intestine," Journal of Nutrition, vol. 131, no. 7, pp. 2007-2013, 2001.

[38] V. J. Johnson and R. P. Sharma, "Aluminum disrupts the proinflammatory cytokine/neurotrophin balance in primary brain rotation-mediated aggregate cultures: possible role in neurodegeneration," NeuroToxicology, vol. 24, no. 2, pp. 261268, 2003.

[39] W. J. Lukiw, M. E. Percy, and T. P. Kruck, "Nanomolar aluminum induces pro-inflammatory and pro-apoptotic gene expression in human brain cells in primary culture," Journal of Inorganic Biochemistry, vol. 99, no. 9, pp. 18951898, 2005.

[40] R. Lin, X. Chen, W. Li, Y. Han, P. Liu, and R. Pi, "Exposure to metal ions regulates mRNA levels of APP and BACE1 in PC12 cells: blockage by curcumin," Neuroscience Letters, vol. 440, no. 3, pp. 344-347, 2008.

[41] J. R. Walton and M. X. Wang, "APP expression, distribution and accumulation are altered by aluminum in a rodent model for Alzheimer's disease," Journal of Inorganic Biochemistry, vol. 103, no. 11, pp. 1548-1554, 2009.

[42] T. García, J. L. Esparza, M. Giralt, M. Romeu, J. L. Domingo, and M. Gómez, "Protective role of melatonin on oxidative stress status and RNA expression in cerebral cortex and cerebellum of a $\beta p p$ transgenic mice after chronic exposure to aluminum," Biological Trace Element Research, vol. 135, no. 1-3, pp. 220-232, 2010.

[43] Y. Luo, F. Niu, Z. Sun et al., "Altered expression of $\mathrm{A} \beta$ metabolism-associated molecules from d-galactose $/ \mathrm{AlCl}_{3}$ induced mouse brain," Mechanisms of Ageing and Development, vol. 130, no. 4, pp. 248-252, 2009.

[44] A. Castorina, A. Tiralongo, S. Giunta, M. L. Carnazza, G. Scapagnini, and V. D'Agata, "Early effects of aluminum chloride on beta-secretase mRNA expression in a neuronal model of $\beta$-amyloid toxicity," Cell Biology and Toxicology, vol. 26, no. 4, pp. 367-377, 2010.

[45] J. M. Socorro, R. Olmo, C. Teijon, M. D. Blanco, and J. M. Teijon, "Analysis of aluminum-yeast hexokinase interaction: modifications on protein structure and functionality," Journal of Protein Chemistry, vol. 19, no. 3, pp. 199-208, 2000.

[46] J. C. K. Lai and J. P. Blass, "Inhibition of brain glycolysis by aluminum," Journal of Neurochemistry, vol. 42, no. 2, pp. 438-446, 1984. 
[47] S. W. Cho and J. G. Joshi, "Inactivation of bakers' yeast glucose-6-phosphate dehydrogenase by aluminum," Biochemistry, vol. 28, no. 8, pp. 3613-3618, 1989.

[48] V. Kumar, A. Bal, and K. D. Gill, "Impairment of mitochondrial energy metabolism in different regions of rat brain following chronic exposure to aluminium," Brain Research, vol. 1232, pp. 94-103, 2008.

[49] J. Lemire, R. Mailloux, S. Puiseux-Dao, and V. D. Appanna, "Aluminum-induced defective mitochondrial metabolism perturbs cytoskeletal dynamics in human astrocytoma cells," Journal of Neuroscience Research, vol. 87, no. 6, pp. 14741483, 2009.

[50] R. J. Mailloux, R. Hamel, and V. D. Appanna, "Aluminum toxicity elicits a dysfunctional TCA cycle and succinate accumulation in hepatocytes," Journal of Biochemical and Molecular Toxicology, vol. 20, no. 4, pp. 198-208, 2006.

[51] K. Shetty, T. Veeranna, and S. C. Guru, "Phosphatase activity against neurofilament proteins from bovine spinal cord: effect of aluminium and neuropsychoactive drugs," Neuroscience Letters, vol. 137, no. 1, pp. 83-86, 1992.

[52] G. V. W. Johnson, K. W. Cogdill, and R. S. Jope, "Oral alumimum alters in vitro protein phosphorylation and kinase activities in rat brain," Neurobiology of Aging, vol. 11, no. 3, pp. 209-216, 1990.

[53] D. Julka and K. D. Gill, "Involvement of altered cytoskeletal protein phosphorylation in aluminum-induced CNS dysfunction," Journal of Biochemical Toxicology, vol. 11, no. 5, pp. 227-233, 1996.

[54] A. Kaur, K. Joshi, R. W. Minz, and K. D. Gill, "Neurofilament phosphorylation and disruption: a possible mechanism of chronic aluminium toxicity in Wistar rats," Toxicology, vol. 219, no. 1-3, pp. 1-10, 2006.

[55] J. C. Troncoso, J. L. March, M. Haner, and U. Aebi, "Effect of aluminum and other multivalent cations on neurofilaments in vitro: an electron microscopic study," Journal of Structural Biology, vol. 103, no. 1, pp. 2-12, 1990.

[56] H. Yamamoto, Y. Saitoh, S. Yasugawa, and E. Miyamoto, "Dephosphorylation of $\tau$ factor by protein phosphatase $2 \mathrm{~A}$ in synaptosomal cytosol fractions, and inhibition by aluminum," Journal of Neurochemistry, vol. 55, no. 2, pp. 683-690, 1990.

[57] A. H. El-Sebae, M. E. Abdel-Ghany, D. Shalloway, M. M. A. Zeid, J. Blancato, and M. A. Saleh, "Aluminum interaction with human brain tau protein phosphorylation by various kinases," Journal of Environmental Science and Health Part B, vol. 28, no. 6, pp. 763-777, 1993.

[58] J. Diaz-Nido and J. Avila, "Aluminum induces the in vitro aggregation of bovine brain cytoskeletal proteins," Neuroscience Letters, vol. 110, no. 1-2, pp. 221-226, 1990.

[59] S. K. Abd-Elghaffar, G. H. El-Sokkary, and A. A. Sharkawy, "Aluminum-induced neurotoxicity and oxidative damage in rabbits: protective effect of melatonin," Neuroendocrinology Letters, vol. 26, no. 5, pp. 609-616, 2005.

[60] S. P. Guy, D. Jones, D. M. A. Mann, and R. F. Itzhaki, "Human neuroblastoma cells treated with aluminium express an epitope associated with Alzheimer's disease neurofibrillary tangles," Neuroscience Letters, vol. 121, no. 1-2, pp. 166-168, 1991.

[61] M. Kawahara, K. Muramoto, K. Kobayashi, and Y. Kuroda, "Functional and morphological changes in cultured neurons of rat cerebral cortex induced by long-term application of aluminum," Biochemical and Biophysical Research Communications, vol. 189, no. 3, pp. 1317-1322, 1992.
[62] J. Savory, Y. Huang, M. M. Herman, M. R. Reyes, and M. R. Wills, "Tau immunoreactivity associated with aluminum maltolate-induced neurofibrillary degeneration in rabbits," Brain Research, vol. 669, no. 2, pp. 325-329, 1995.

[63] T. Kihira, S. Yoshida, Y. Yase, S. Ono, and T. Kondo, "Chronic low-Ca/Mg high-Al diet induces neuronal loss," Neuropathology, vol. 22, no. 3, pp. 171-179, 2002.

[64] M. Kawahara, M. Kato, and Y. Kuroda, "Effects of aluminum on the neurotoxicity of primary cultured neurons and on the aggregation of $\beta$-amyloid protein," Brain Research Bulletin, vol. 55, no. 2, pp. 211-217, 2001.

[65] A. Campbell, A. Kumar, F. G. La Rosa, K. N. Prasad, and S. C. Bondy, "Aluminum increases levels of $\beta$-amyloid and ubiquitin in neuroblastoma but not in glioma cells," Proceedings of the Society for Experimental Biology and Medicine, vol. 223, no. 4, pp. 397-402, 2000.

[66] D. Praticò, K. Uryu, S. Sung, S. Tang, J. Q. Trojanowski, and V. M. Lee, "Aluminum modulates brain amyloidosis through oxidative stress in APP transgenic mice," The FASEB Journal, vol. 16, no. 9, pp. 1138-1140, 2002.

[67] L. F. Rodella, F. Ricci, E. Borsani et al., "Aluminium exposure induces Alzheimer's disease-like histopathological alterations in mouse brain," Histology and Histopathology, vol. 23, no. 46, pp. 433-439, 2008.

[68] S. D. Provan and R. A. Yokel, "Aluminum inhibits glutamate release from transverse rat hippocampal slices: role of $\mathrm{G}$ proteins, Ca channels and protein kinase C," NeuroToxicology, vol. 13, no. 2, pp. 413-420, 1992.

[69] J. J. Canales, R. Corbalán, C. Montoliu et al., "Aluminium impairs the glutamate-nitric oxide-cGMP pathway in cultured neurons and in rat brain in vivo: molecular mechanisms and implications for neuropathology," Journal of Inorganic Biochemistry, vol. 87, no. 1, pp. 63-69, 2001.

[70] H. Meiri, E. Banin, M. Roll, and A. Rousseau, "Toxic effects of aluminium on nerve cells and synaptic transmission," Progress in Neurobiology, vol. 40, no. 1, pp. 89-121, 1993.

[71] S. J. Yang, J. W. Huh, J. E. Lee, S. Y. Choi, T. U. Kim, and S. W. Cho, "Inactivation of human glutamate dehydrogenase by aluminum," Cellular and Molecular Life Sciences, vol. 60, no. 11, pp. 2538-2546, 2003.

[72] C. M. Nday, B. D. Drever, T. Salifoglou, and B. Platt, "Aluminium interferes with hippocampal calcium signaling in a species-specific manner," Journal of Inorganic Biochemistry, vol. 104, pp. 919-927, 2010.

[73] J. R. Hofstetter, I. Vincent, O. Bugiani, B. Ghetti, and J. A. Richter, "Aluminum-induced decreases in choline acetyltransferase, tyrosine hydroxylase, and glutamate decarboxylase in selected regions of rabbit brain," Neurochemical Pathology, vol. 6, no. 3, pp. 177-193, 1987.

[74] P. Zatta, M. Ibn-Lkhayat-Idrissi, P. Zambenedetti, M. Kilyen, and T. Kiss, "In vivo and in vitro effects of aluminum on the activity of mouse brain acetylcholinesterase," Brain Research Bulletin, vol. 59, no. 1, pp. 41-45, 2002.

[75] H. Bielarczyk, M. Tomaszewicz, and A. Szutowicz, "Effect of aluminum on acetyl-CoA and acetylcholine metabolism in nerve terminals," Journal of Neurochemistry, vol. 70, no. 3, pp. 1175-1181, 1998.

[76] K. S. J. Rao and G. V. Rao, "Effect of aluminium (Al) on brain mitochondrial monoamine oxidase-A (MAO-A) activity - an in vitro kinetic study," Molecular and Cellular Biochemistry, vol. 137, no. 1, pp. 57-60, 1994.

[77] P. Zatta, P. Zambenedetti, and M. Milanese, "Activation of monoamine oxidase type-B by aluminum in rat brain 
homogenate," NeuroReport, vol. 10, no. 17, pp. 3645-3648, 1999.

[78] M. Milanese, M. I. Lkhayat, and P. Zatta, "Inhibitory effect of aluminum on dopamine $\beta$-hydroxylase from bovine adrenal gland," Journal of Trace Elements in Medicine and Biology, vol. 15, no. 2-3, pp. 139-141, 2001.

[79] J. C. K. Lai, L. Lim, and A. N. Davison, "Effects of $\mathrm{Cd}^{2+}$, $\mathrm{Mn}^{2+}$, and $\mathrm{AI}^{2+}$ on rat brain synaptosomal uptake of noradrenaline and serotonin," Journal of Inorganic Biochemistry, vol. 17, no. 3, pp. 215-225, 1982.

[80] M. Kanazirska, P. P. Vassilev, S. Y. Birzon, and P. M. Vassilev, "Voltage-dependent effect of $\mathrm{AI}^{3+}$ on channel activities in hippocampal neurons," Biochemical and Biophysical Research Communications, vol. 232, no. 1, pp. 84-87, 1997.

[81] T. Csóti, J. Gyri, J. Salánki, and L. Erdélyi, "pH-dependent actions of aluminum on voltage-activated sodium currents in snail neurons," NeuroToxicology, vol. 22, no. 1, pp. 109-116, 2001.

[82] B. Platt and D. Busselberg, "Combined actions of $\mathrm{Pb}^{2+}, \mathrm{Zn}^{2+}$, and $\mathrm{AI}^{2+}$ on voltage-activated calcium channel currents," Cellular and Molecular Neurobiology, vol. 14, no. 6, pp. 831840, 1994.

[83] S. Pentyala, J. Ruggeri, A. Veerraju et al., "Microsomal $\mathrm{Ca}^{2+}$ flux modulation as an indicator of heavy metal toxicity," Indian Journal of Experimental Biology, vol. 48, no. 7, pp. 737$743,2010$.

[84] L. Li, "The biochemistry and physiology of metallic fluoride: action, mechanism, and implications," Critical Reviews in Oral Biology and Medicine, vol. 14, no. 2, pp. 100-114, 2003.

[85] C. Theiss and K. Meller, "Aluminum impairs gap junctional intercellular communication between astroglial cells in vitro," Cell and Tissue Research, vol. 310, no. 2, pp. 143-154, 2002.

[86] A. Bizzi, R. C. Crane, L. Autilio Gambetti, and P. Gambetti, "Aluminum effect on slow axonal transport: a novel impairment of neurofilament transport," Journal of Neuroscience, vol. 4, no. 3, pp. 722-731, 1984.

[87] N. Siegel, C. Suhayda, and A. Haug, "Aluminum changes the conformation of calmodulin," Physiological Chemistry and Physics, vol. 14, no. 2, pp. 165-167, 1982.

[88] A. Campbell, A. Becaria, D. K. Lahiri, K. Sharman, and S. C. Bondy, "Chronic exposure to aluminum in drinking water increases inflammatory parameters selectively in the brain," Journal of Neuroscience Research, vol. 75, no. 4, pp. 565-572, 2004.

[89] P. I. Oteiza, "A mechanism for the stimulatory effect of aluminum on iron-induced lipid peroxidation," Archives of Biochemistry and Biophysics, vol. 308, no. 2, pp. 374-379, 1994.

[90] N. Kaneko, T. Sugioka, and H. Sakurai, "Aluminum compounds enhance lipid peroxidation in liposomes: insight into cellular damage caused by oxidative stress," Journal of Inorganic Biochemistry, vol. 101, no. 6, pp. 967-975, 2007.

[91] S. V. Verstraeten and P. I. Oteiza, "Al-mediated changes in membrane physical properties participate in the inhibition of polyphosphoinositide hydrolysis," Archives of Biochemistry and Biophysics, vol. 408, no. 2, pp. 263-271, 2002.

[92] J. D. Pandya, K. R. Dave, and S. S. Katyare, "Effect of longterm aluminum feeding on lipid/phospholipid profiles of rat brain myelin," Lipids in Health and Disease, vol. 3, article no. 13, 2004.

[93] V. S. Silva, J. M. Cordeiro, M. J. Matos, C. R. Oliveira, and P. P. Gonçalves, "Aluminum accumulation and membrane fluidity alteration in synaptosomes isolated from rat brain cortex following aluminum ingestion: effect of cholesterol," Neuroscience Research, vol. 44, no. 2, pp. 181-193, 2002.

[94] O. Ghribi, M. M. Herman, M. S. Forbes, D. A. DeWitt, and J. Savory, "GDNF protects against aluminum-induced apoptosis in rabbits by upregulating Bcl-2 and Bcl-X and inhibiting mitochondrial Bax translocation," Neurobiology of Disease, vol. 8, no. 5, pp. 764-773, 2001.

[95] M. Kawahara, M. Kato-Negishi, R. Hosoda, L. Imamura, M. Tsuda, and Y. Kuroda, "Brain-derived neurotrophic factor protects cultured rat hippocampal neurons from aluminum maltolate neurotoxicity," Journal of Inorganic Biochemistry, vol. 97, no. 1, pp. 124-131, 2003.

[96] G. W. Guo and Y. X. Liang, "Aluminum-induced apoptosis in cultured astrocytes and its effect on calcium homeostasis," Brain Research, vol. 888, no. 2, pp. 221-226, 2001.

[97] M. J. Strong and R. M. Garruto, "Neuron-specific thresholds of aluminum toxicity in vitro: a comparative analysis of dissociated fetal rabbit hippocampal and motor neuronenriched cultures," Laboratory Investigation, vol. 65, no. 2, pp. 243-249, 1991.

[98] C. A. Shaw and M. S. Petrik, "Aluminum hydroxide injections lead to motor deficits and motor neuron degeneration," Journal of Inorganic Biochemistry, vol. 103, no. 11, pp. 15551562, 2009.

[99] B. Platt, D. O. Carpenter, D. Busselberg, K. G. Reymann, and G. Riedel, "Aluminum impairs hippocampal long-term potentiation in rats in vitro and in vivo," Experimental Neurology, vol. 134, no. 1, pp. 73-86, 1995.

[100] M. Wang, J. T. Chen, D. Y. Ruan, and Y. Z. Xu, "The influence of developmental period of aluminum exposure on synaptic plasticity in the adult rat dentate gyrus in vivo," Neuroscience, vol. 113, no. 2, pp. 411-419, 2002.

[101] R. A. Yokel, D. D. Allen, and J. J. Meyer, "Studies of aluminum neurobehavioral toxicity in the intact mammal," Cellular and Molecular Neurobiology, vol. 14, no. 6, pp. 791-808, 1994.

[102] N. Kaneko, J. Takada, H. Yasui, and H. Sakurai, "Memory deficit in mice administered aluminum-maltolate complex," BioMetals, vol. 19, no. 1, pp. 83-89, 2006.

[103] J. R. Walton, "A longitudinal study of rats chronically exposed to aluminum at human dietary levels," Neuroscience Letters, vol. 412, no. 1, pp. 29-33, 2007.

[104] P. Sethi, A. Jyoti, R. Singh, E. Hussain, and D. Sharma, "Aluminium-induced electrophysiological, biochemical and cognitive modifications in the hippocampus of aging rats," NeuroToxicology, vol. 29, no. 6, pp. 1069-1079, 2008.

[105] D. Ribes, M. T. Colomina, P. Vicens, and J. L. Domingo, "Effects of oral aluminum exposure on behavior and neurogenesis in a transgenic mouse model of Alzheimer's disease," Experimental Neurology, vol. 214, no. 2, pp. 293-300, 2008.

[106] D. Ribes, M. T. Colomina, P. Vicens, and J. L. Domingo, "Impaired spatial learning and unaltered neurogenesis in a transgenic model of alzheimer's disease after oral aluminum exposure," Current Alzheimer Research, vol. 7, no. 5, pp. 401408, 2010.

[107] P. Zatta, P. Zambenedetti, E. Reusche et al., "A fatal case of aluminium encephalopathy in a patient with severe chronic renal failure not on dialysis," Nephrology Dialysis Transplantation, vol. 19, no. 11, pp. 2929-2931, 2004.

[108] H. M. Wisniewski and G. Y. Wen, "Aluminium and Alzheimer's disease," Ciba Foundation Symposium, vol. 169, pp. 142-154, 1992.

[109] D. Shore and R. J. Wyatt, "Aluminum and Alzheimer's disease," Journal of Nervous and Mental Disease, vol. 171, no. 9, pp. 553-558, 1983. 
[110] R. Doll, "Review: Alzheimer's disease and environmental aluminium," Age and Ageing, vol. 22, no. 2, pp. 138-153, 1993.

[111] C. R. Harrington, C. M. Wischik, F. K. McArthur, G. A. Taylor, J. A. Edwardson, and J. M. Candy, "Alzheimer'sdisease-like changes in tau protein processing: association with aluminium accumulation in brains of renal dialysis patients," The Lancet, vol. 343, no. 8904, pp. 993-997, 1994.

[112] C. W. Scott, A. Fieles, L. A. Sygowski, and C. B. Caputo, "Aggregation of tau protein by aluminum," Brain Research, vol. 628, no. 1-2, pp. 77-84, 1993.

[113] R. A. Crowther, "Straight and paired helical filaments in Alzheimer disease have a common structural unit," Proceedings of the National Academy of Sciences of the United States of America, vol. 88, no. 6, pp. 2288-2292, 1991.

[114] E. Bjertness, J. M. Candy, A. Torvik et al., "Content of brain aluminum is not elevated in Alzheimer disease," Alzheimer Disease and Associated Disorders, vol. 10, no. 3, pp. 171-174, 1996.

[115] J. P. Landsberg, B. McDonald, and F. Watt, "Absence of aluminium in neuritic plaque cores in Alzheimer's disease," Nature, vol. 360, no. 6399, pp. 65-68, 1992.

[116] C. Bouras, P. Giannakopoulos, P. F. Good, A. Hsu, P. R. Hof, and D. P. Perl, "A laser microprobe mass analysis of brain aluminum and iron in dementia pugilistica: comparison with Alzheimer's disease," European Neurology, vol. 38, no. 1, pp. 53-58, 1997.

[117] J. M. Candy, F. K. McArthur, A. E. Oakley et al., "Aluminium accumulation in relation to senile plaque and neurofibrillary tangle formation in the brains of patients with renal failure," Journal of the Neurological Sciences, vol. 107, no. 2, pp. 210 218, 1992.

[118] S. Yumoto, S. Kakimi, A. Ohsaki, and A. Ishikawa, "Demonstration of aluminum in amyloid fibers in the cores of senile plaques in the brains of patients with Alzheimer's disease," Journal of Inorganic Biochemistry, vol. 103, no. 11, pp. 15791584, 2009.

[119] A. Wettstein, J. Aeppli, K. Gautschi, and M. Peters, "Failure to find a relationship between mnestic skills of octagenarians and aluminum in drinking water," International Archives of Occupational and Environmental Health, vol. 63, no. 2, pp. 97-103, 1991.

[120] C. N. Martyn, D. N. Coggon, H. Inskip, R. F. Lacey, and W. F. Young, "Aluminum concentrations in drinking water and risk of Alzheimer's disease," Epidemiology, vol. 8, no. 3, pp. 281-286, 1997.

[121] D. R. C. McLachlan, C. Bergeron, J. E. Smith, D. Boomer, and S. L. Rifat, "Risk for neuropathologically confirmed Alzheimer's disease and residual aluminum in municipal drinking water employing weighted residential histories," Neurology, vol. 46, no. 2, pp. 401-405, 1996.

[122] E. Gauthier, I. Fortier, F. Courchesne, P. Pepin, J. Mortimer, and D. Gauvreau, "Aluminum forms in drinking water and risk of Alzheimer's disease," Environmental Research, vol. 84, no. 3, pp. 234-246, 2000.

[123] J. D. Birchall and J. S. Chappell, "The chemistry of aluminum and silicon in relation to Alzheimer's disease," Clinical Chemistry, vol. 34, no. 2, pp. 265-267, 1988.

[124] J. A. Edwardson, P. B. Moore, I. N. Ferrier et al., "Effect of silicon on gastrointestinal absorption of aluminium," The Lancet, vol. 342, no. 8865, pp. 211-212, 1993.

[125] S. Gillete-Guyonnet, S. Andrieu, F. Nourhashemi, V. de la Guéronnière, H. Grandjean, and B. Vellas, "Cognitive impairment and composition of drinking water in women: findings of the EPIDOS study," American Journal of Clinical Nutrition, vol. 81, no. 4, pp. 897-902, 2005.

[126] A. Goate, M. C. Chartier-Harlin, M. Mullan et al., "Segregation of a missense mutation in the amyloid precursor protein gene with familial Alzheimer's disease," Nature, vol. 349, no. 6311, pp. 704-706, 1991.

[127] B. A. Yankner, L. K. Duffy, and D. A. Kirschner, "Neurotrophic and neurotoxic effects of amyloid $\beta$ protein: reversal by tachykinin neuropeptides," Science, vol. 250, no. 4978, pp. 279-282, 1990.

[128] C. J. Pike, D. Burdick, A. J. Walencewicz, C. G. Glabe, and C. W. Cotman, "Neurodegeneration induced by $\beta$-amyloid peptides in vitro: the role of peptide assembly state," Journal of Neuroscience, vol. 13, no. 4, pp. 1676-1687, 1993.

[129] L. K. Simmons, P. C. May, K. J. Tomaselli et al., "Secondary structure of amyloid $\beta$ peptide correlates with neurotoxic activity in vitro," Molecular Pharmacology, vol. 45, no. 3, pp. 373-379, 1994.

[130] D. J. Selkoe, "Soluble oligomers of the amyloid $\beta$-protein impair synaptic plasticity and behavior," Behavioural Brain Research, vol. 192, no. 1, pp. 106-113, 2008.

[131] C. Exley, N. C. Price, S. M. Kelly, and J. D. Birchall, "An interaction of $\beta$-amyloid with aluminium in vitro," FEBS Letters, vol. 324, no. 3, pp. 293-295, 1993.

[132] P. W. Mantyh, J. R. Ghilardi, S. Rogers et al., "Aluminum, iron, and zinc ions promote aggregation of physiological concentrations of $\beta$-amyloid peptide," Journal of Neurochemistry, vol. 61, no. 3, pp. 1171-1174, 1993.

[133] M. Kawahara, K. Muramoto, K. Bobayashi, H. Mori, and Y. Kuroda, "Aluminum promotes the aggregation of Alzheimer's amyloid $\beta$-protein in vitro," Biochemical and Biophysical Research Communications, vol. 198, no. 2, pp. 531-535, 1994.

[134] Y. Kuroda and M. Kawahara, "Aggregation of amyloid betaprotein and its neurotoxicity: enhancement by aluminum and other metals," Tohoku Journal of Experimental Medicine, vol. 174, no. 3, pp. 263-268, 1994.

[135] G. D. Fasman, A. Perczel, and C. D. Moore, "Solubilization of $\beta$-amyloid-(1-42)-peptide: reversing the $\beta$-sheet conformation induced by aluminum with silicates," Proceedings of the National Academy of Sciences of the United States of America, vol. 92, no. 2, pp. 369-371, 1995.

[136] E. House, J. Collingwood, A. Khan, O. Korchazkina, G. Berthon, and C. Exley, "Aluminium, iron, zinc and copper Influence the in vitro formation of amyloid fibrils of $A \beta 42$ in a manner which may have consequences for metal chelation therapy in Alzheimer's disease," Journal of Alzheimer's Disease, vol. 6, no. 3, pp. 291-301, 2004.

[137] S. C. Bondy and A. Truong, "Potentiation of beta-folding of $\beta$-amyloid peptide $25-35$ by aluminum salts," Neuroscience Letters, vol. 267, no. 1, pp. 25-28, 1999.

[138] Y. H. Chong and Y. H. Suh, "Aggregation of amyloid precursor proteins by aluminum in vitro," Brain Research, vol. 670, no. 1, pp. 137-141, 1995.

[139] H. Murayama, R.-W. Shin, J. Higuchi, S. Shibuya, T. Muramoto, and T. Kitamoto, "Interaction of aluminum with PHFtau in Alzheimer's disease neurofibrillary degeneration evidenced by desferrioxamine-assisted chelating autoclave method," American Journal of Pathology, vol. 155, no. 3, pp. 877-885, 1999.

[140] S. R. Paik, J. H. Lee, D. H. Kim, C. S. Chang, and J. Kim, "Aluminum-induced structural alterations of the precursor of the non-A $\beta$ component of Alzheimer's disease amyloid," 
Archives of Biochemistry and Biophysics, vol. 344, no. 2, pp. 325-334, 1997.

[141] V. N. Uversky, J. Li, and A. L. Fink, "Metal-triggered structural transformations, aggregation, and fibrillation of human $\alpha$-synuclein: a possible molecular link between parkinson's disease and heavy metal exposure," Journal of Biological Chemistry, vol. 276, no. 47, pp. 44284-44296, 2001.

[142] B. Ward, K. Walker, and C. Exley, "Copper(II) inhibits the formation of amylin amyloid in vitro," Journal of Inorganic Biochemistry, vol. 102, no. 2, pp. 371-375, 2008.

[143] A. Khan, A. E. Ashcroft, O. V. Korchazhkina, and C. Exley, "Metal-mediated formation of fibrillar ABri amyloid," Journal of Inorganic Biochemistry, vol. 98, no. 12, pp. 2006-2010, 2004.

[144] F. Ricchelli, P. Fusi, P. Tortora et al., "Destabilization of non-pathological variants of ataxin-3 by metal ions results in aggregation/fibrillogenesis," International Journal of Biochemistry and Cell Biology, vol. 39, no. 5, pp. 966-977, 2007.

[145] M. Chaussidon, P. Netter, M. Kessler et al., "Dialysisassociated arthropathy: secondary ion mass spectrometry evidence of aluminum silicate in $\beta$-microglobulin amyloid synovial tissue and articular cartilage," Nephron, vol. 65, no. 4, pp. 559-563, 1993.

[146] R. Fukuyama, T. Mizuno, T. Mizuno et al., "Age-dependent change in the levels of $A \beta 40$ and $A \beta 42$ in cerebrospinal fluid from control subjects, and a decrease in the ratio of $\mathrm{A} \beta 42$ to $A \beta 40$ level in cerebrospinal fluid from Alzheimer's disease patients," European Neurology, vol. 43, no. 3, pp. 155-160, 2000.

[147] M. Kawahara, "Role of calcium dyshomeostasis via amyloid channels in the pathogenesis of Alzheimer's disease," Current Pharmaceutical Design, vol. 16, pp. 2779-2789, 2010.

[148] T. Dyrks, E. Dyrks, C. L. Masters, and K. Beyreuther, "Amyloidogenicity of rodent and human $\beta A 4$ sequences," FEBS Letters, vol. 324, no. 2, pp. 231-236, 1993.

[149] A. I. Bush, W. H. Pettingell, G. Multhaup et al., "Rapid induction of Alzheimer $\mathrm{A} \beta$ amyloid formation by zinc," Science, vol. 265, no. 5177, pp. 1464-1467, 1994.

[150] C. S. Atwood, R. D. Moir, X. Huang et al., "Dramatic aggregation of alzheimer $\mathrm{A} \beta$ by $\mathrm{Cu}(\mathrm{II})$ is induced by conditions representing physiological acidosis," Journal of Biological Chemistry, vol. 273, no. 21, pp. 12817-12826, 1998.

[151] M. A. Lovell, C. Xie, and W. R. Markesbery, "Protection against amyloid beta peptide toxicity by zinc," Brain Research, vol. 823, no. 1-2, pp. 88-95, 1999.

[152] M. Kawahara, N. Arispe, Y. Kuroda, and E. Rojas, "Alzheimer's disease amyloid $\beta$-protein forms $\mathrm{Zn}^{2+}$-sensitive, cation-selective channels across excised membrane patches from hypothalamic neurons," Biophysical Journal, vol. 73, no. 1, pp. 67-75, 1997.

[153] T. Sakamoto, H. Saito, K. Ishii, H. Takahashi, S. Tanabe, and Y. Ogasawara, "Aluminum inhibits proteolytic degradation of amyloid $\beta$ peptide by cathepsin D: a potential link between aluminum accumulation and neuritic plaque deposition," FEBS Letters, vol. 580, no. 28-29, pp. 6543-6549, 2006.

[154] F. Ricchelli, D. Drago, B. Filippi, G. Tognon, and P. Zatta, "Aluminum-triggered structural modifications and aggregation of $\beta$-amyloids," Cellular and Molecular Life Sciences, vol. 62, no. 15, pp. 1724-1733, 2005.

[155] D. Drago, A. Cavaliere, N. Mascetra et al., "Aluminum modulates effects of $\beta$ amyloid1-42 on neuronal calcium homeostasis and mitochondria functioning and is altered in a triple transgenic mouse model of Alzheimer's disease," Rejuvenation Research, vol. 11, no. 5, pp. 861-871, 2008.
[156] D. Drago, S. Bolognin, and P. Zatta, "Role of metal ions in the $A \beta$ oligomerization in Alzheimer's disease and in other neurological disorders," Current Alzheimer Research, vol. 5, no. 6, pp. 500-507, 2008.

[157] C. Exley and M. M. Esiri, "Severe cerebral congophilic angiopathy coincident with increased brain aluminium in a resident of Camelford, Cornwall, UK," Journal of Neurology, Neurosurgery and Psychiatry, vol. 77, no. 7, pp. 877-879, 2006.

[158] D. L. Dickstein, J. Walsh, H. Brautigam, S. D. Stockton Jr., S. Gandy, and P. R. Hof, "Role of vascular risk factors and vascular dysfunction in Alzheimer's disease," Mount Sinai Journal of Medicine, vol. 77, no. 1, pp. 82-102, 2010.

[159] M. U. Muckenthaler, B. Galy, and M. W. Hentze, "Systemic iron homeostasis and the iron-responsive element/ironregulatory protein (IRE/IRP) regulatory network," Annual Review of Nutrition, vol. 28, pp. 197-213, 2008.

[160] K. Yamanaka, N. Minato, and K. Iwai, "Stabilization of iron regulatory protein 2, IRP2, by aluminum," FEBS Letters, vol. 462, no. 1-2, pp. 216-220, 1999.

[161] R. R. Crichton, S. Wilmet, R. Legssyer, and R. J. Ward, "Molecular and cellular mechanisms of iron homeostasis and toxicity in mammalian cells," Journal of Inorganic Biochemistry, vol. 91, no. 1, pp. 9-18, 2002.

[162] S. Oshiro, M. Kawahara, Y. Kuroda et al., "Glial cells contribute more to iron and aluminum accumulation but are more resistant to oxidative stress than neuronal cells," Biochimica et Biophysica Acta, vol. 1502, no. 3, pp. 405-414, 2000.

[163] H.-H. Cho, C. M. Cahill, C. R. Vanderburg et al., "Selective translational control of the Alzheimer amyloid precursor protein transcript by iron regulatory protein-1," Journal of Biological Chemistry, vol. 285, no. 41, pp. 31217-31232, 2010.

[164] J. A. Duce, A. Tsatsanis, M. A. Cater et al., "Iron-export ferroxidase activity of $\beta$-amyloid precursor protein is inhibited by zinc in Alzheimer's disease," Cell, vol. 142, no. 6, pp. 857$867,2010$.

[165] G. K. W. Kong, L. A. Miles, G. A. N. Crespi et al., "Copper binding to the Alzheimer's disease amyloid precursor protein," European Biophysics Journal, vol. 37, no. 3, pp. 269-279, 2008.

[166] K. Namekata, M. Imagawa, A. Terashi, S. Ohta, F. Oyama, and Y. Ihara, "Association of transferrin C2 allele with lateonset Alzheimer's disease," Human Genetics, vol. 101, no. 2, pp. 126-129, 1997.

[167] D. J. Lehmann, M. Schuur, D. R. Warden et al., “Transferrin and HFE genes interact in Alzheimer's disease risk: the Epistasis Project," Neurobiology of Aging. In press.

[168] M. Imagawa, S. Naruse, S. Tsuji, A. Fujioka, and H. Yamaguchi, "Coenzyme $\mathrm{Q}_{10}$, iron, and vitamin $\mathrm{B}_{6}$ in geneticallyconfirmed Alzheimer's disease," The Lancet, vol. 340, no. 8820, p. 671, 1992.

[169] M. L. Hegde, P. Bharathi, A. Suram et al., "Challenges associated with metal chelation therapy in alzheimer's disease," Journal of Alzheimer's Disease, vol. 17, no. 3, pp. 457-468, 2009.

[170] A. I. Bush and R. E. Tanzi, "Therapeutics for Alzheimer's disease based on the metal hypothesis," Neurotherapeutics, vol. 5, no. 3, pp. 421-432, 2008.

[171] R. A. Yokel, "Aluminum chelation: chemistry, clinical, and experimental studies and the search for alternatives to desferrioxamine," Journal of Toxicology and Environmental Health, vol. 41, no. 2, pp. 131-174, 1994. 
[172] C. Exley, "Organosilicon therapy in Alzheimer's disease?" Journal of Alzheimer's Disease, vol. 11, no. 3, pp. 301-302, 2007.

[173] M. Kawahara, K. Konoha, T. Nagata, and Y. Sadakane, "Aluminum and human health: its intake, bioavailability and neurotoxicity," Biomedical Research on Trace Elements, vol. 18, pp. 111-120, 2007.

[174] S. Yumoto, H. Nagai, K. Kobayashi, A. Tamate, S. Kakimi, and H. Matsuzaki, "Al incorporation into the brain of suckling rats through maternal milk," Journal of Inorganic Biochemistry, vol. 97, no. 1, pp. 155-160, 2003.

[175] N. D. Priest, "The biological behaviour and bioavailability of aluminium in man, with special reference to studies employing aluminium-26 as a tracer: review and study update," Journal of Environmental Monitoring, vol. 6, no. 5, pp. 375-403, 2004.

[176] M. Kawahara, "Auminum and human health: possible link with neurodegenerative disorders," in Metals and Neurodegeneration, S. Huang, Ed., pp. 15-56, Research Signpost, 2010. 


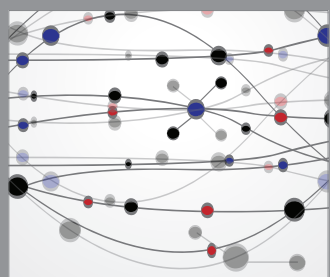

The Scientific World Journal
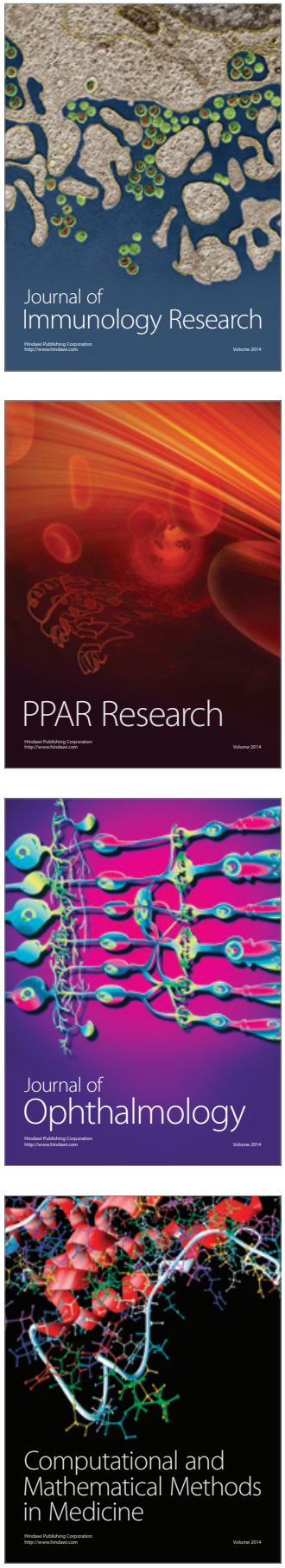

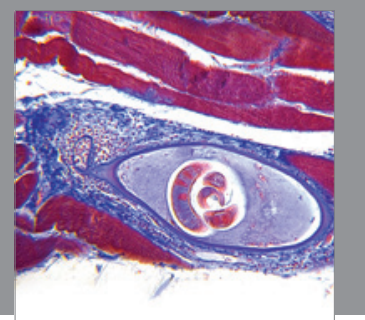

Gastroenterology

Research and Practice
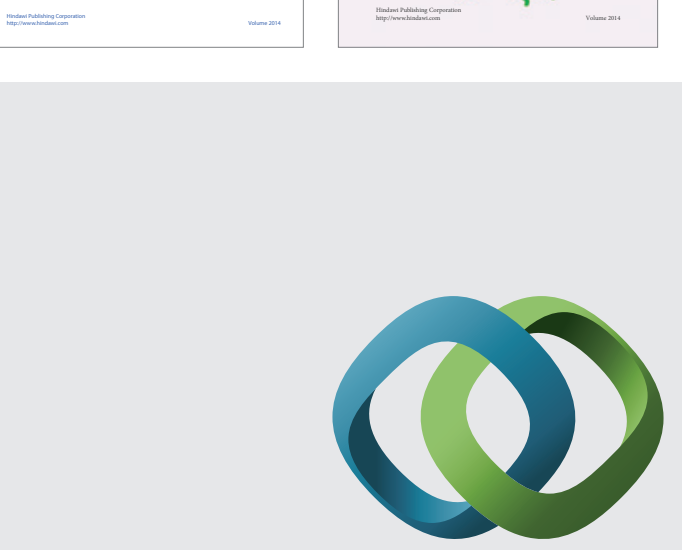

\section{Hindawi}

Submit your manuscripts at

http://www.hindawi.com
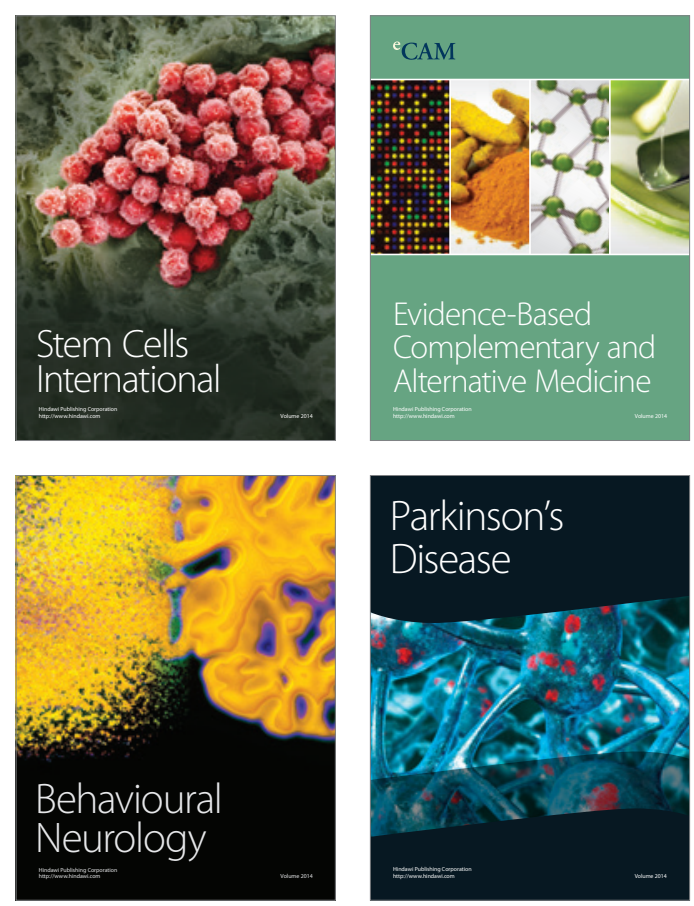

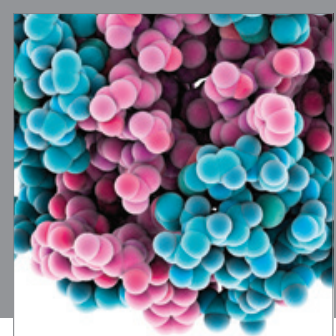

Journal of
Diabetes Research

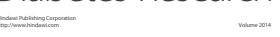

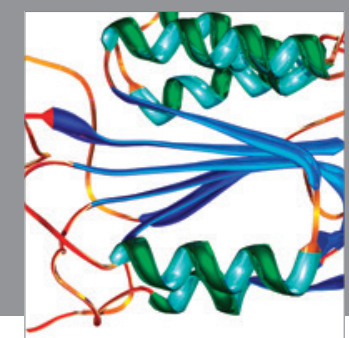

Disease Markers
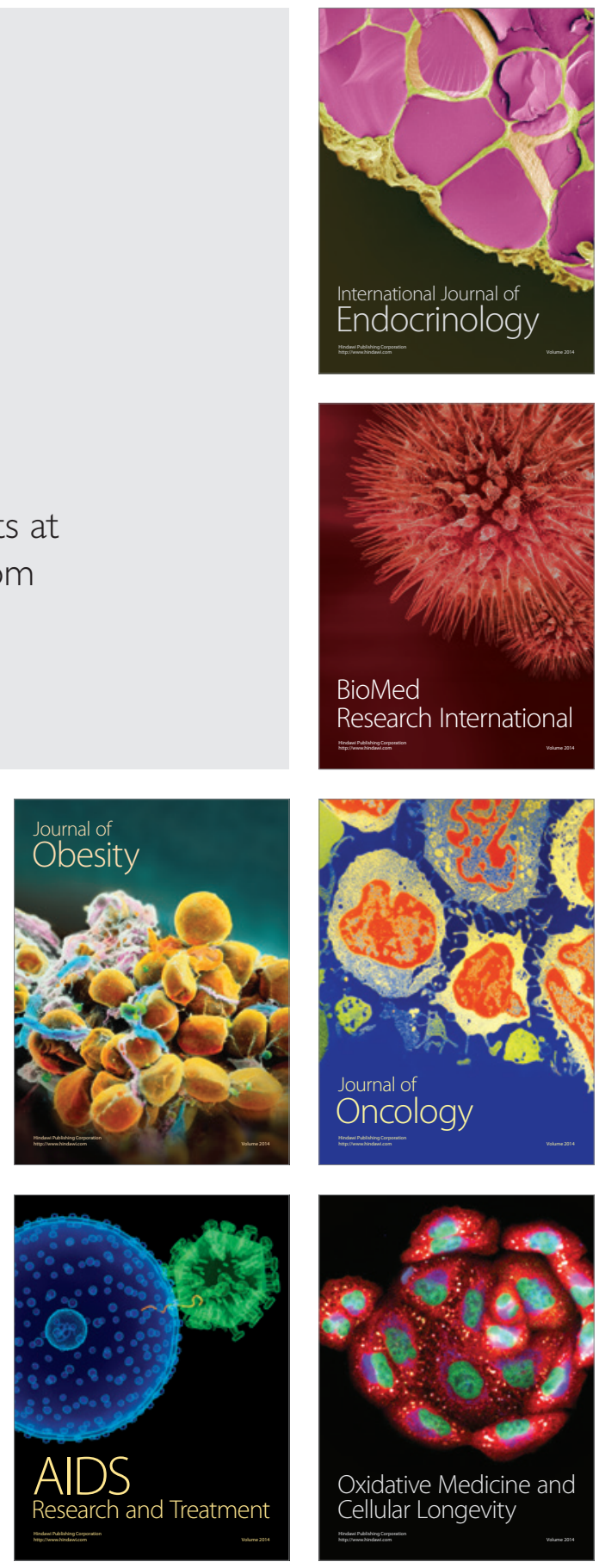